\title{
Asymmetric orbifolds: Path integral and operator formulations
}

\section{Citation}

Narain, K.S., M.H. Sarmadi, and C. Vafa. 1991. “Asymmetric Orbifolds: Path

Integral and Operator Formulations." Nuclear Physics B 356 (1): 163-207. https://

doi.org/10.1016/0550-3213(91)90145-n.

\section{Permanent link}

http://nrs.harvard.edu/urn-3:HUL.InstRepos:41385049

\section{Terms of Use}

This article was downloaded from Harvard University's DASH repository, and is made available under the terms and conditions applicable to Other Posted Material, as set forth at http:// nrs.harvard.edu/urn-3:HUL.InstRepos:dash.current.terms-of-use\#LAA

\section{Share Your Story}

The Harvard community has made this article openly available.

Please share how this access benefits you. Submit a story.

Accessibility 
CERN-TH.5846/90

$90-10-310$

HUTP-90/A053

\title{
ASYMMETRIC ORBIFOLDS:
}

PATH INTEGRAL AND OPERATOR FORMULATIONS

\author{
K.S. Narain, M.H. Sarmadi \\ Theory Division, CERN \\ CH-1211 Geneva 23, Switzerland \\ and \\ C. Vafa \\ Lyman Laboratory of Physics, Harvard University \\ Cambridge, MA 02198, USA
}

\begin{abstract}
We discuss some of the details involved in asymmetric orbifold construction. In particular, the path integral formalism is developed and shown to be consistent with operator interpretation. Conditions of one-loop modular invariance are discussed in detail. We also describe how one can construct correlation functions involving twisted states.
\end{abstract}

CERN-TH.5846/90

HUTP-90/A053

August 1990 


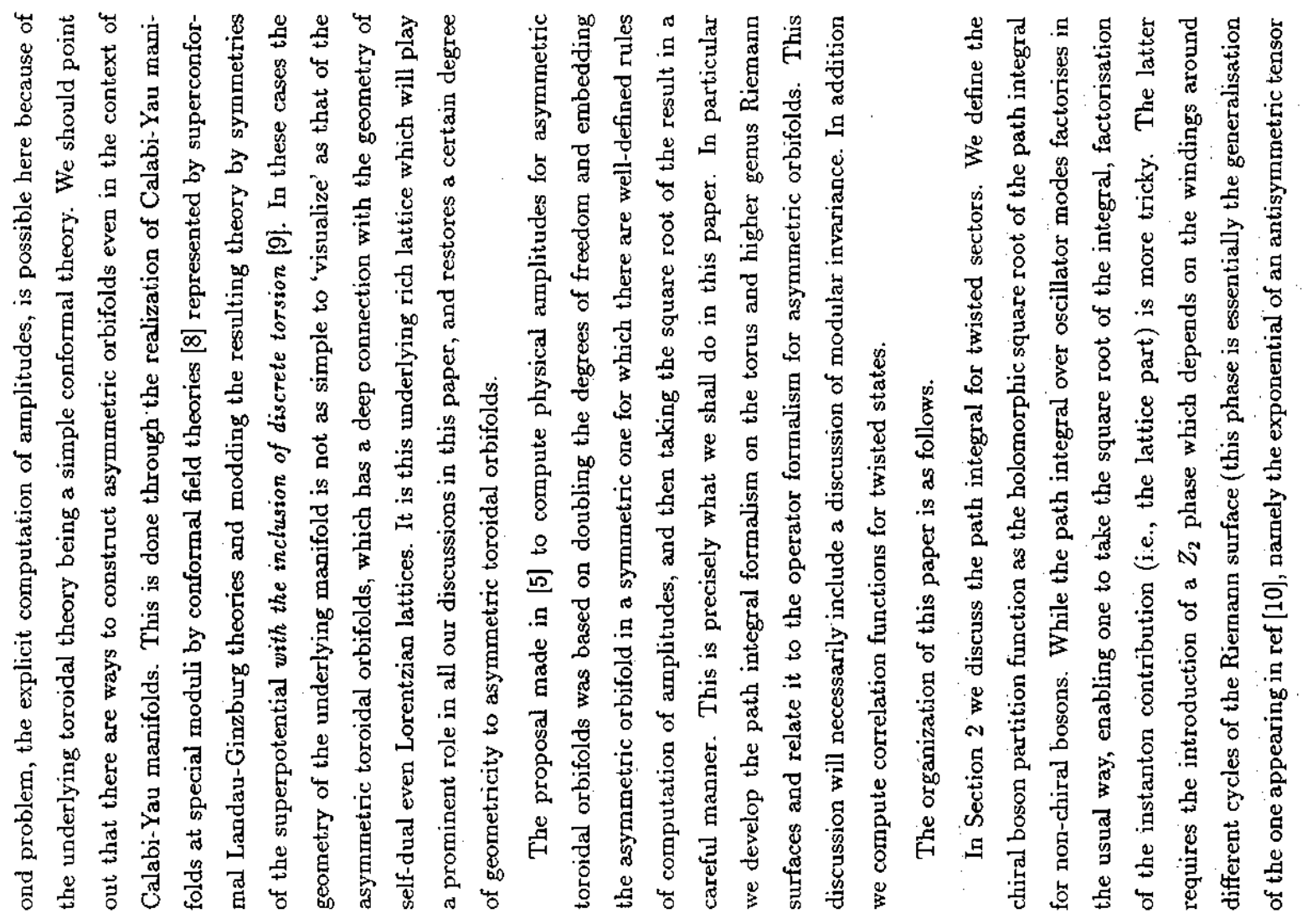

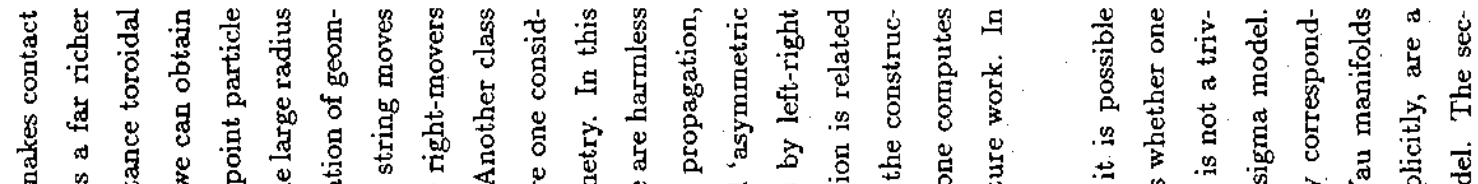

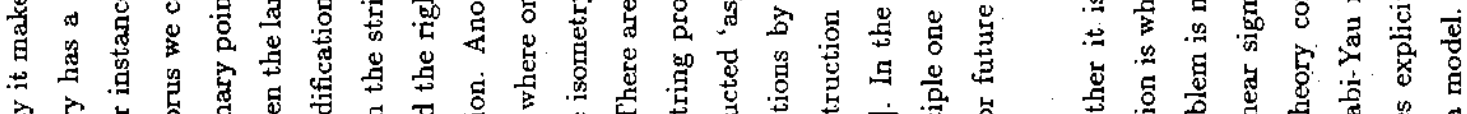

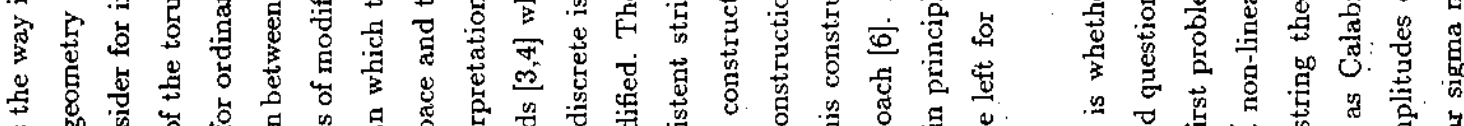

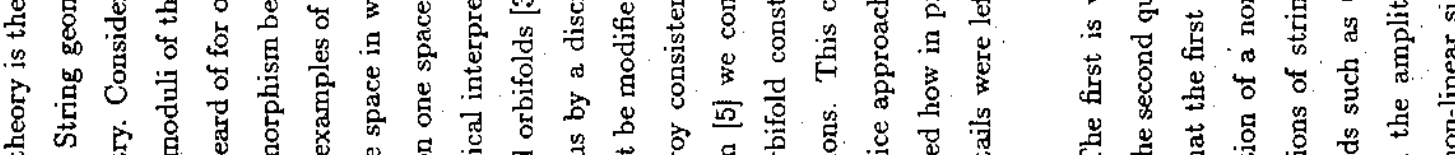

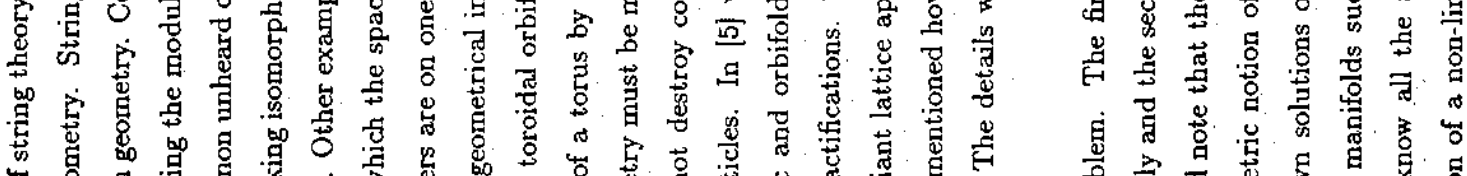

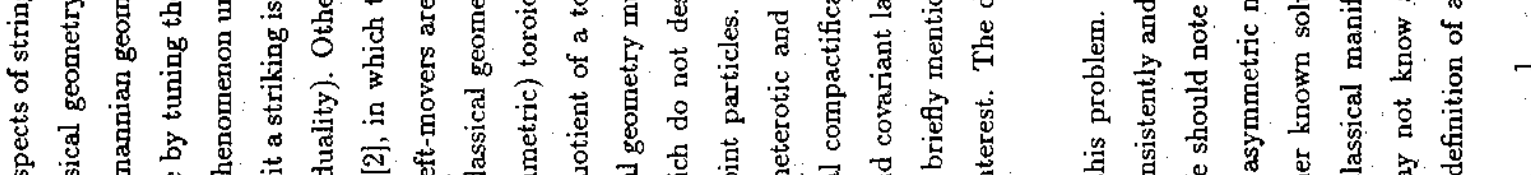

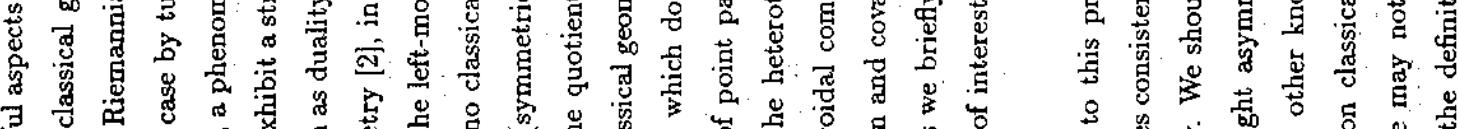

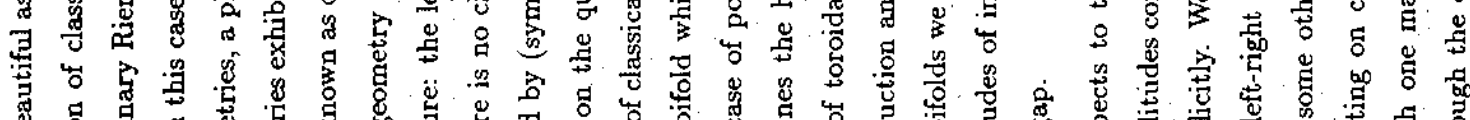

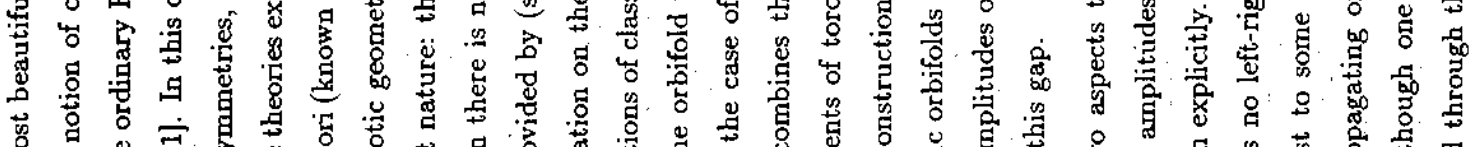

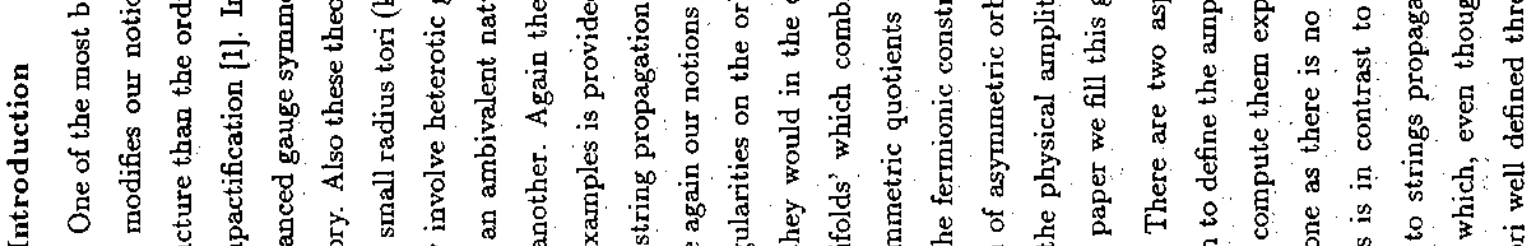

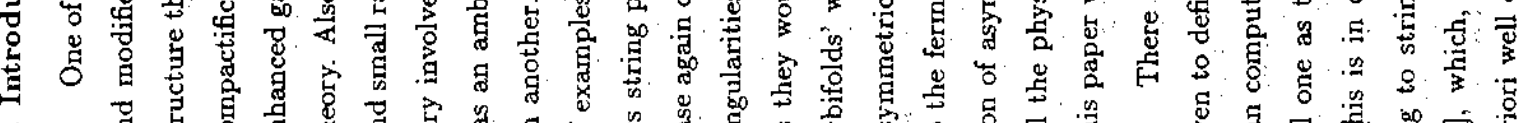

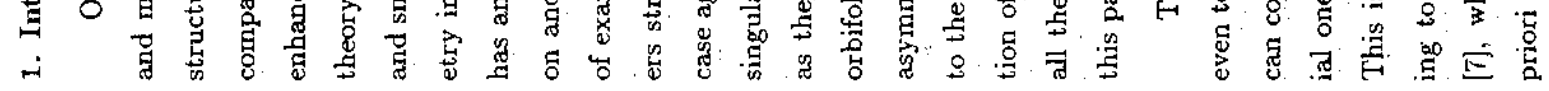




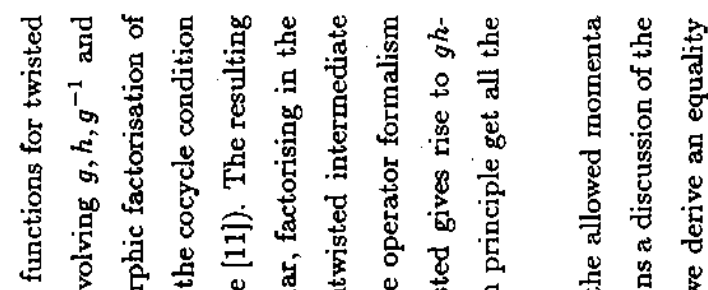

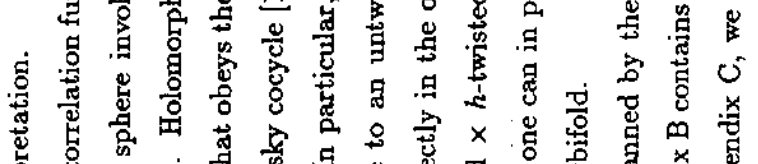

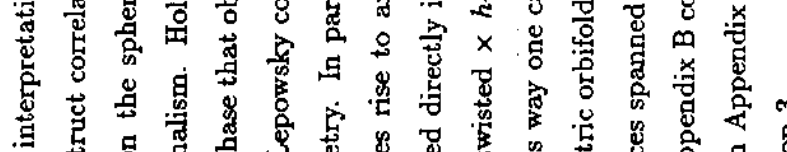

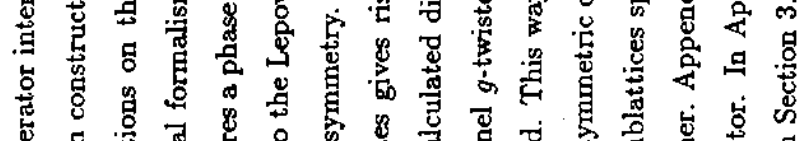

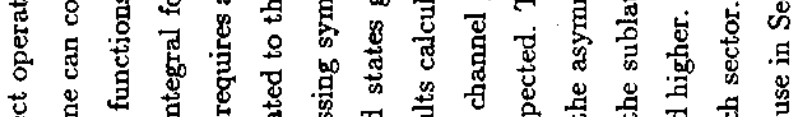

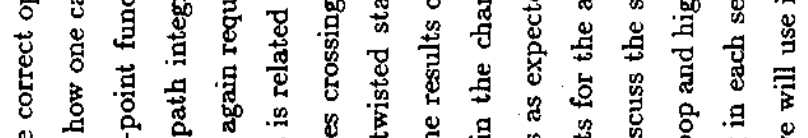

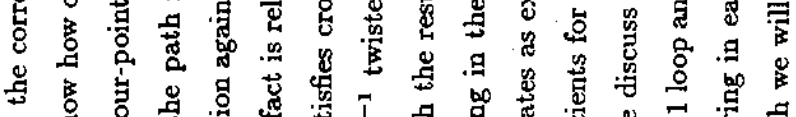

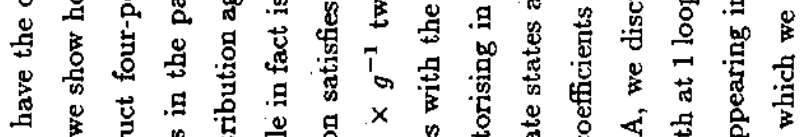

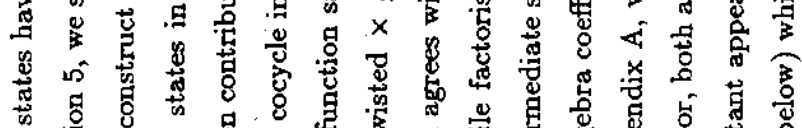

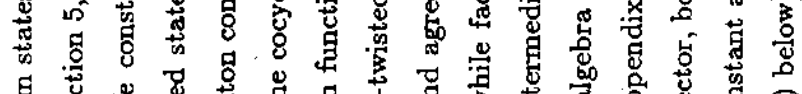

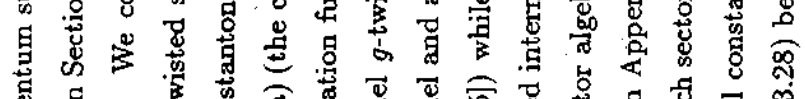

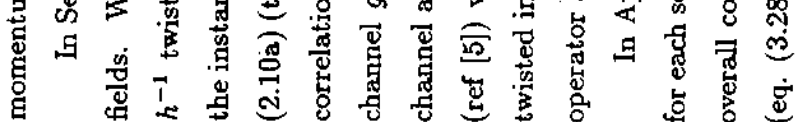

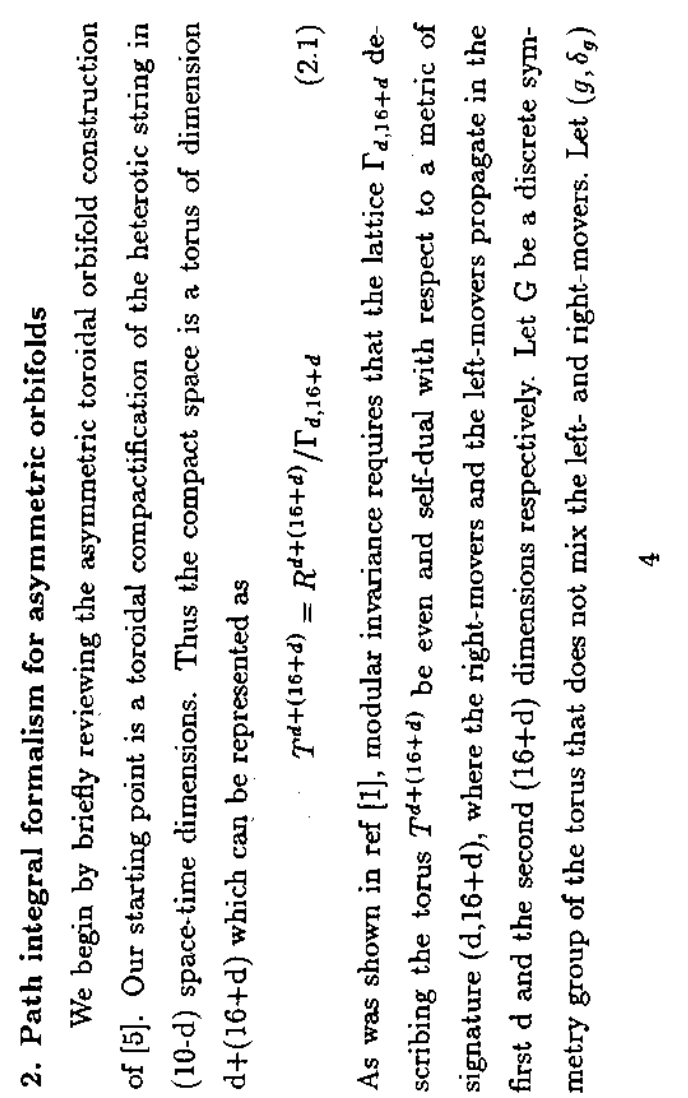

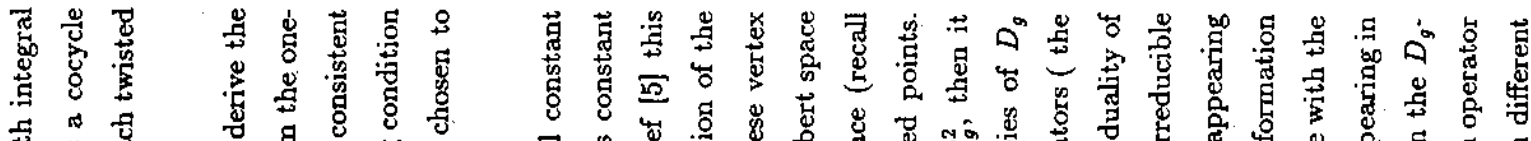

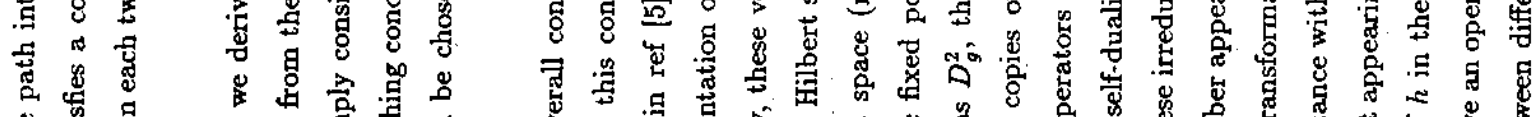

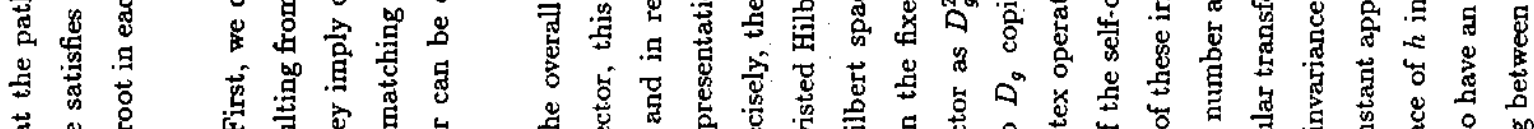

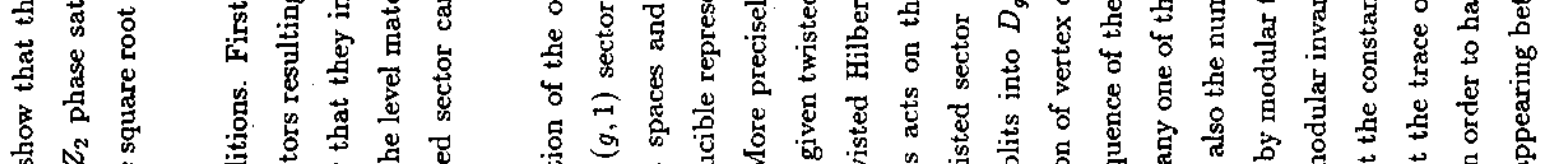

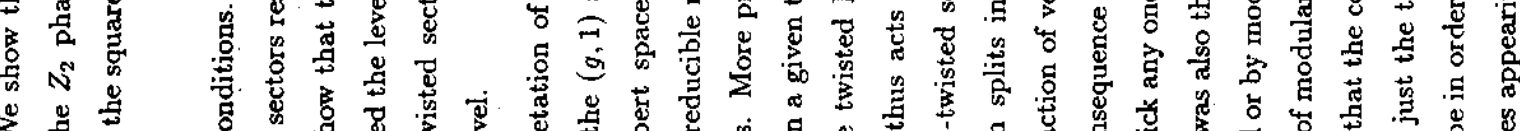

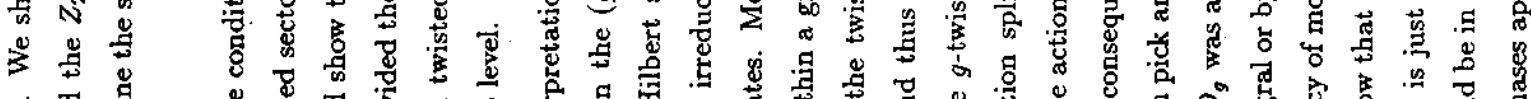

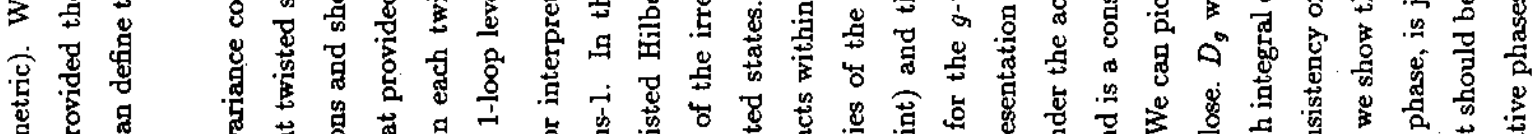

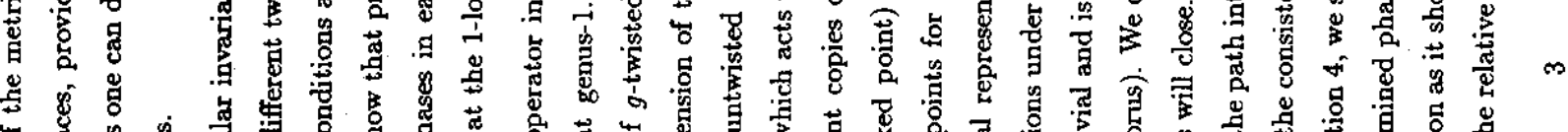

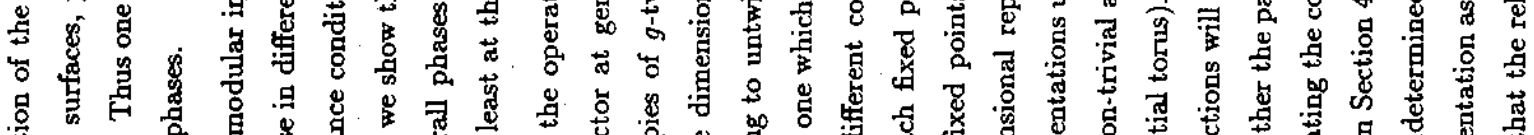

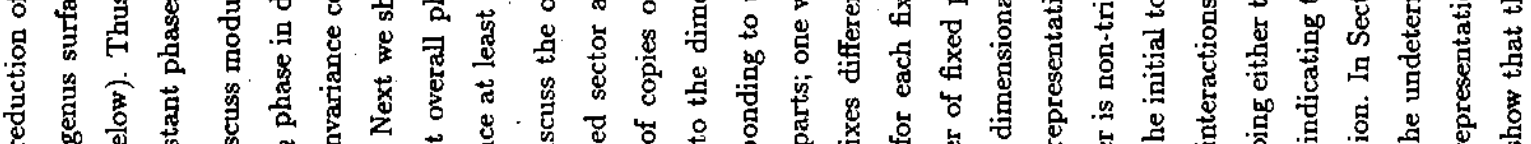

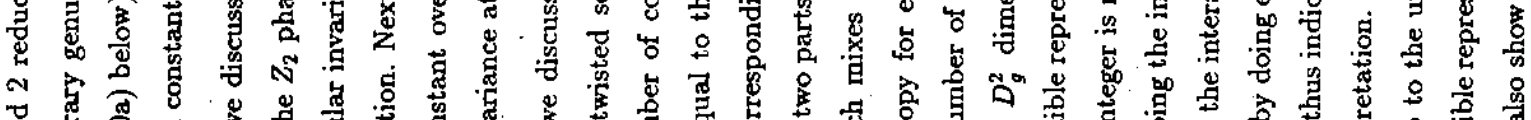

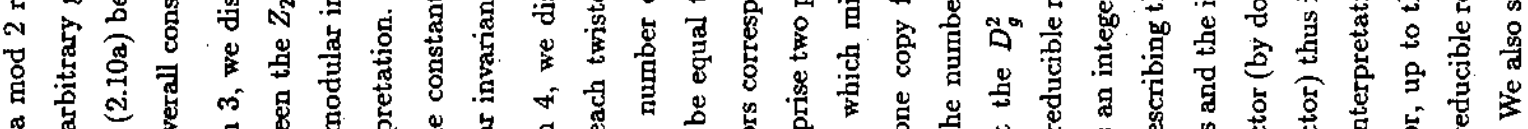

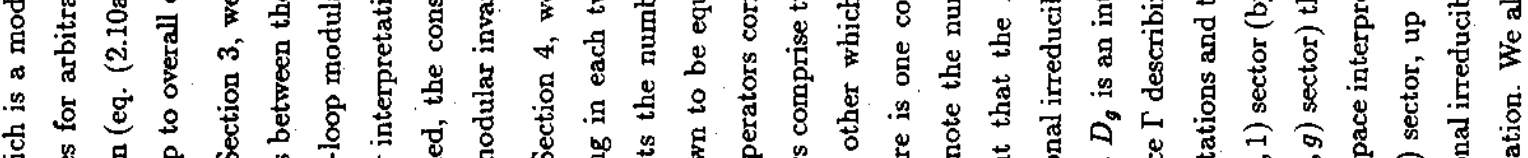

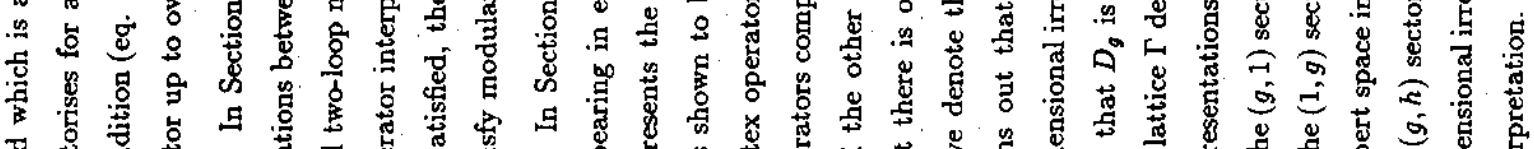

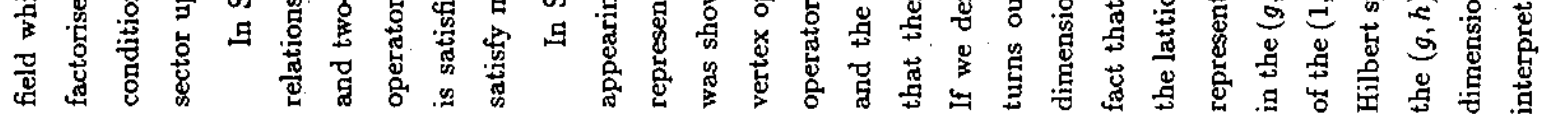




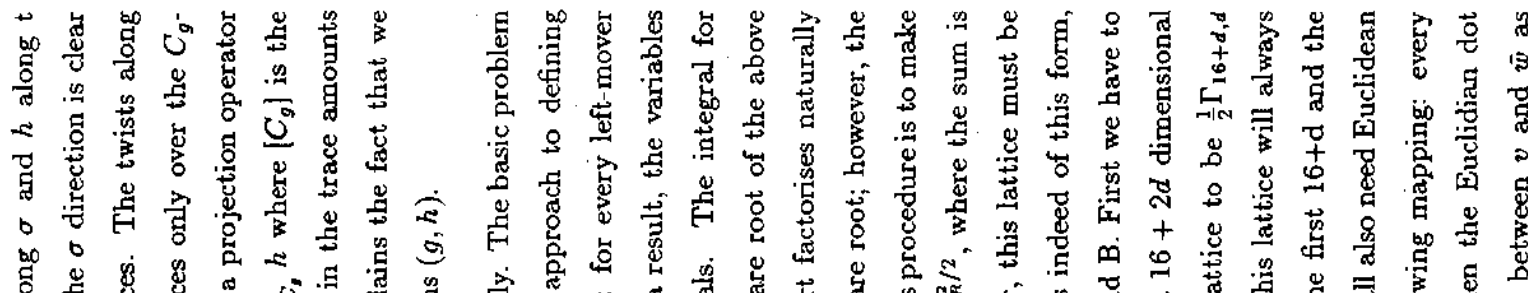

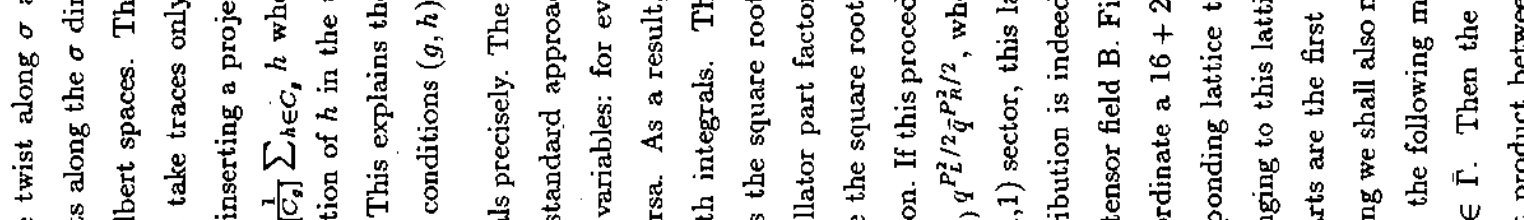

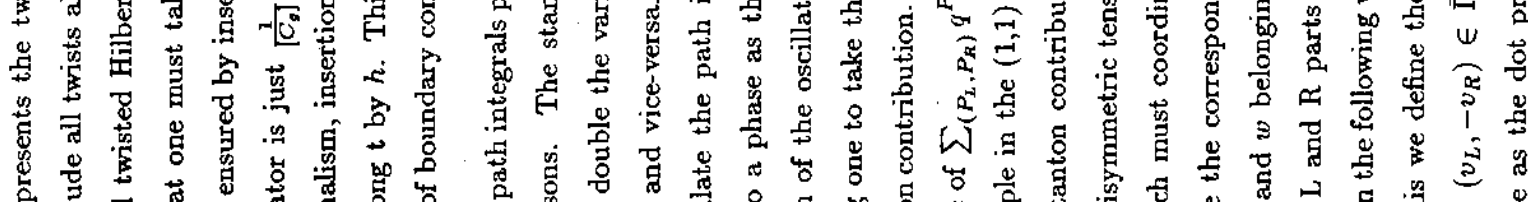

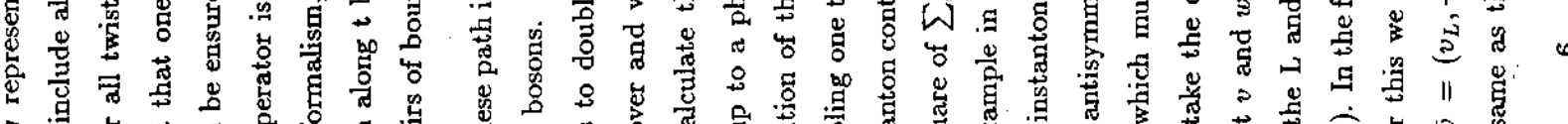

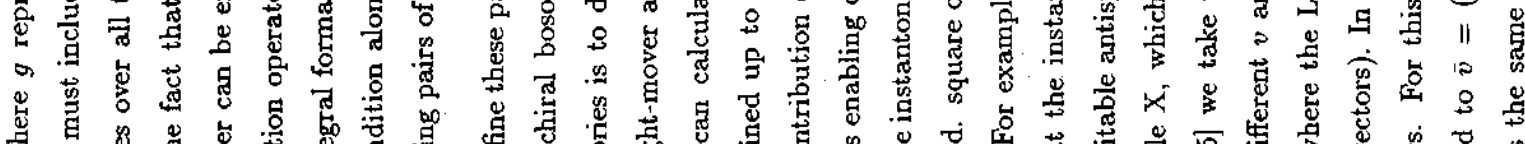

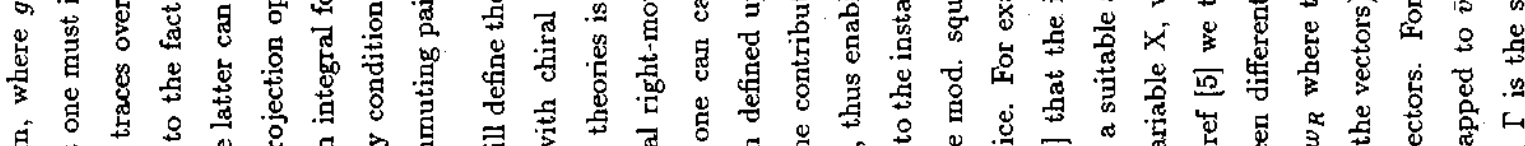
Oring

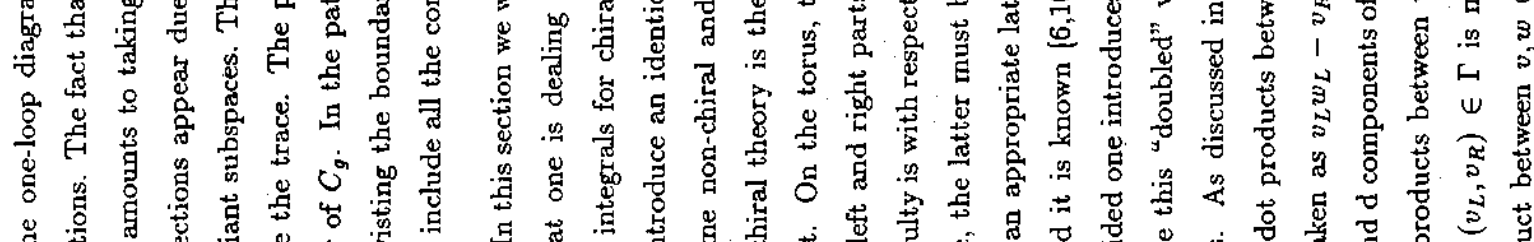

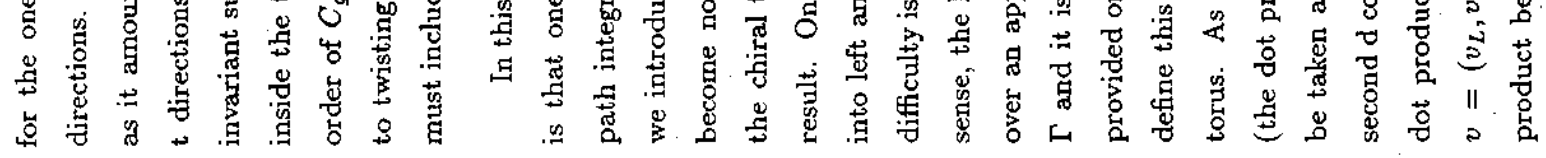

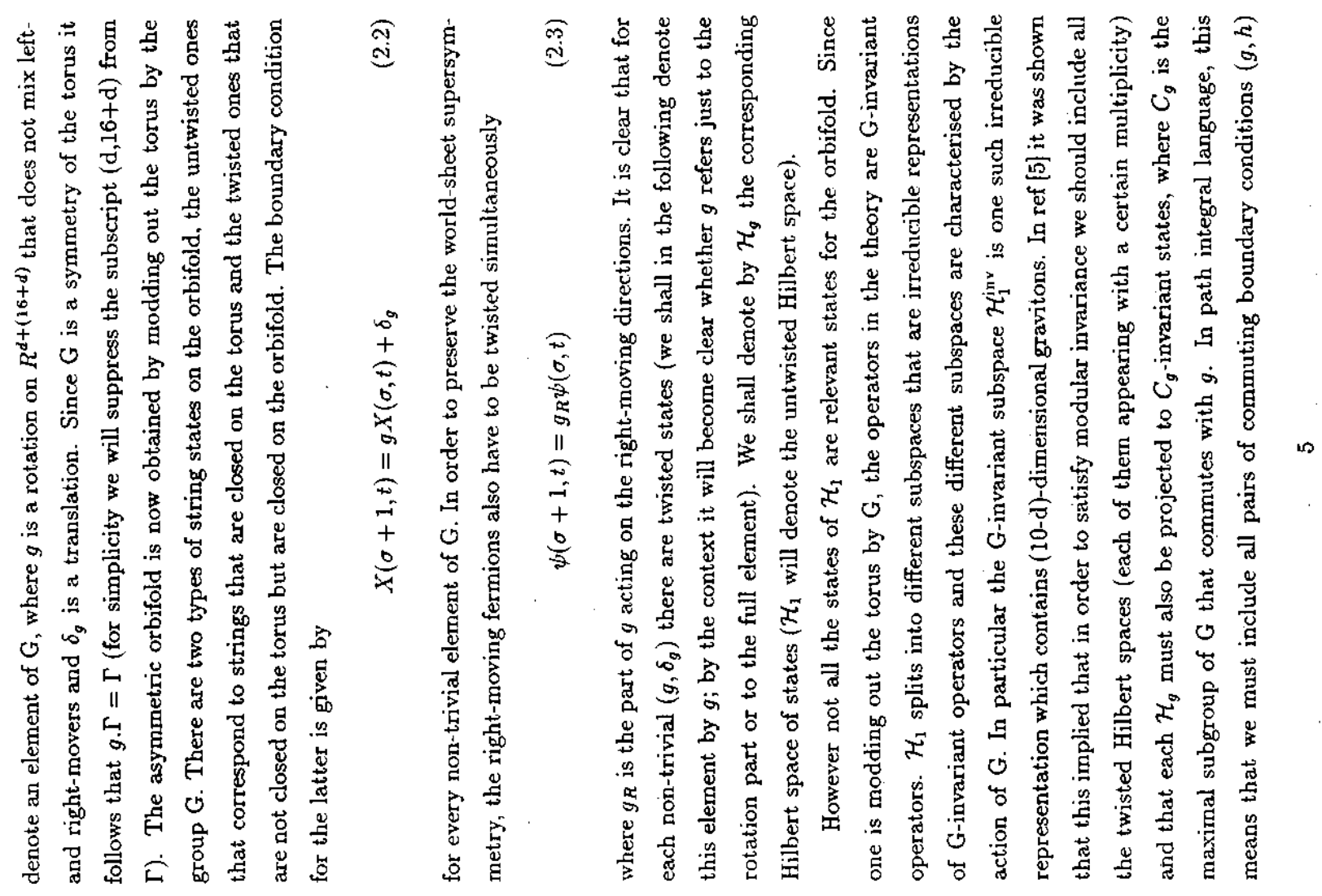



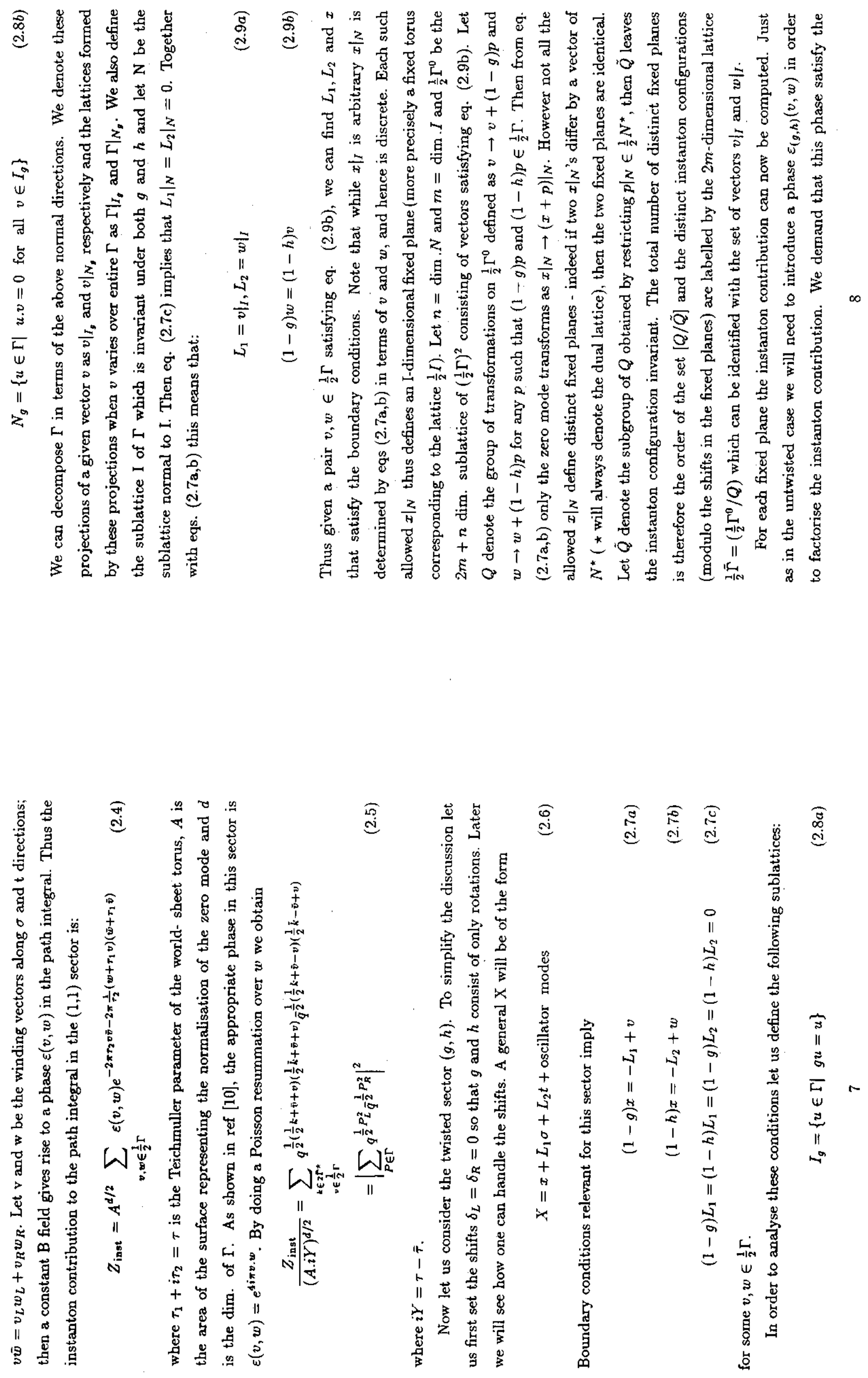

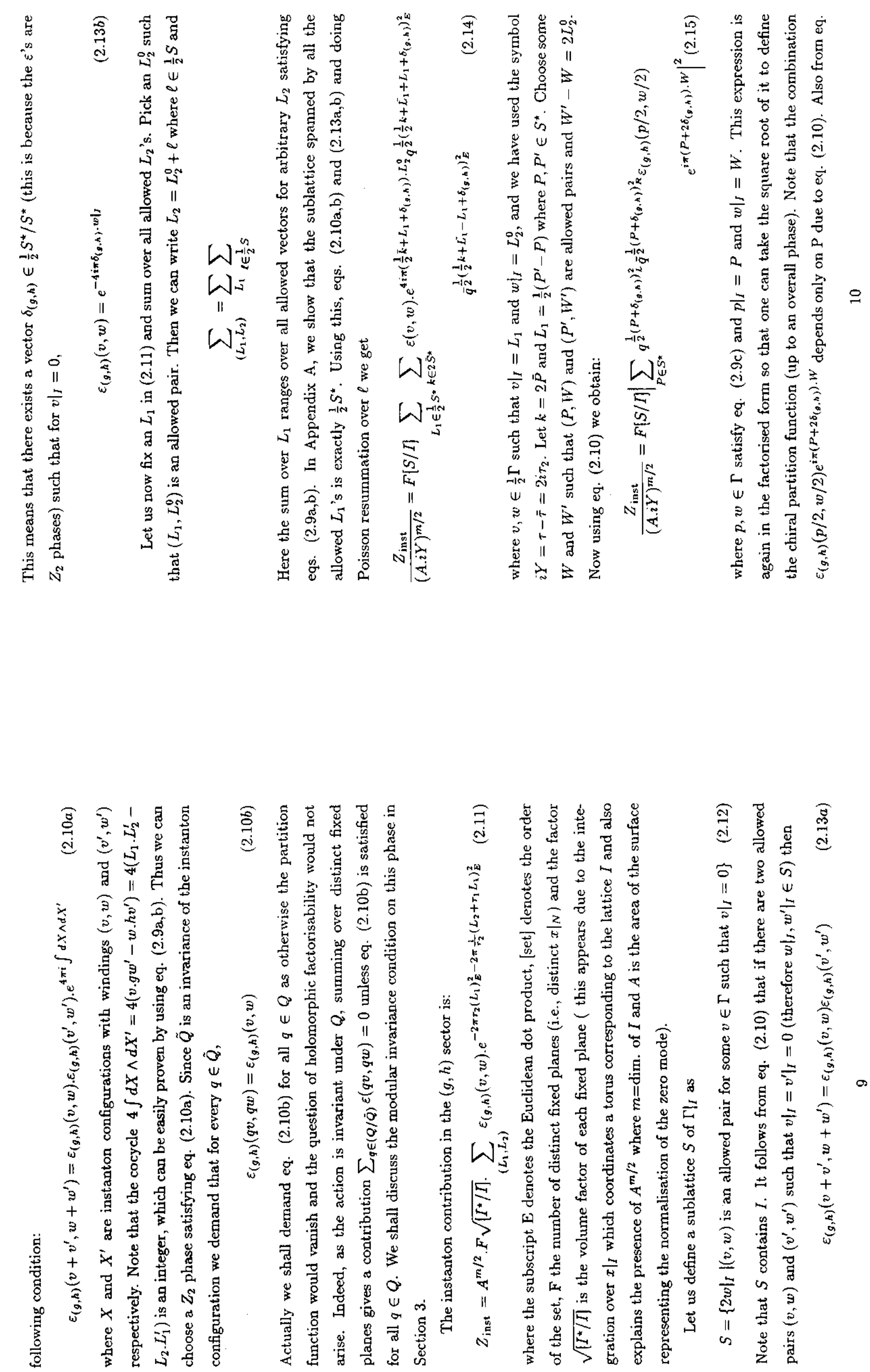


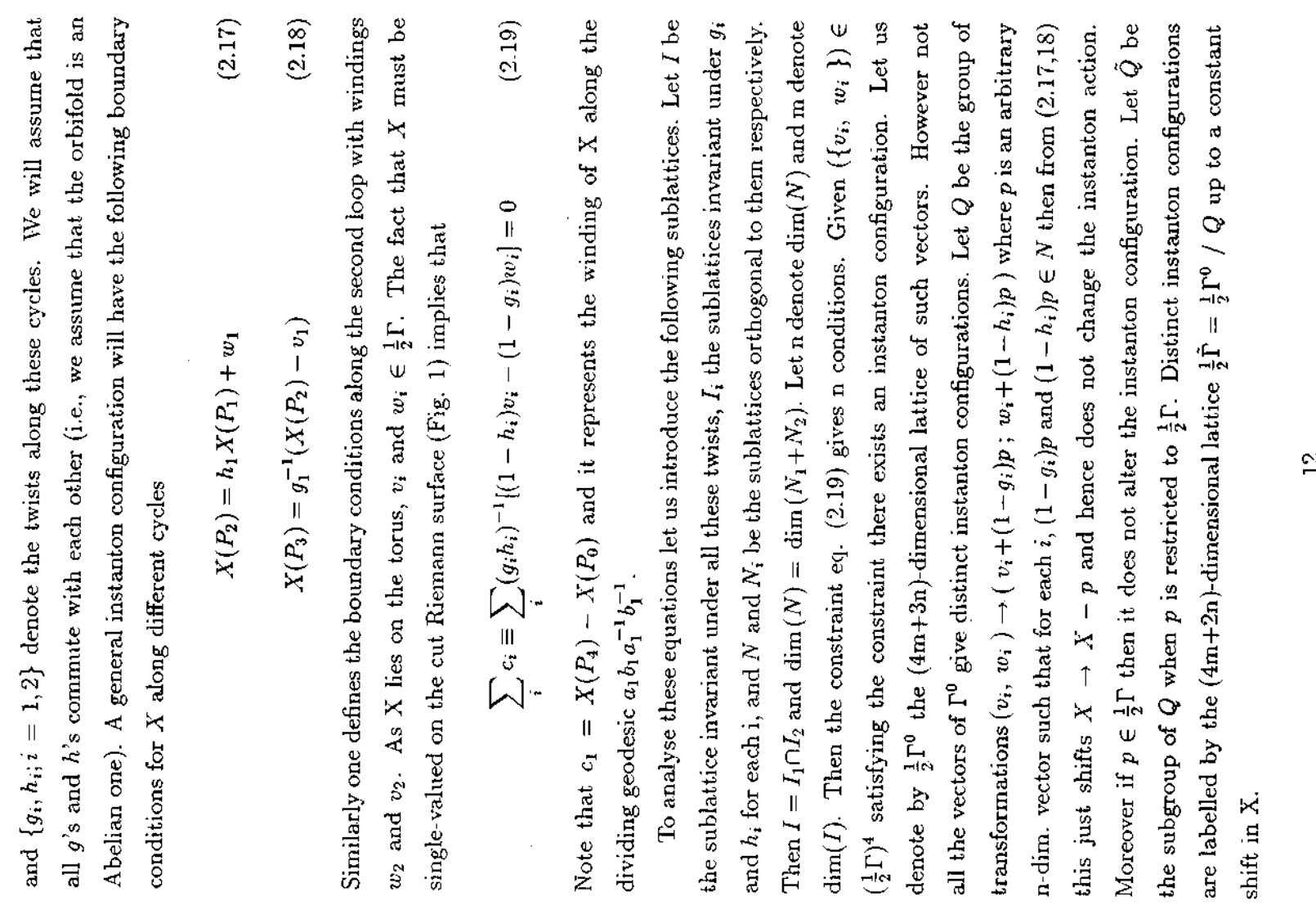

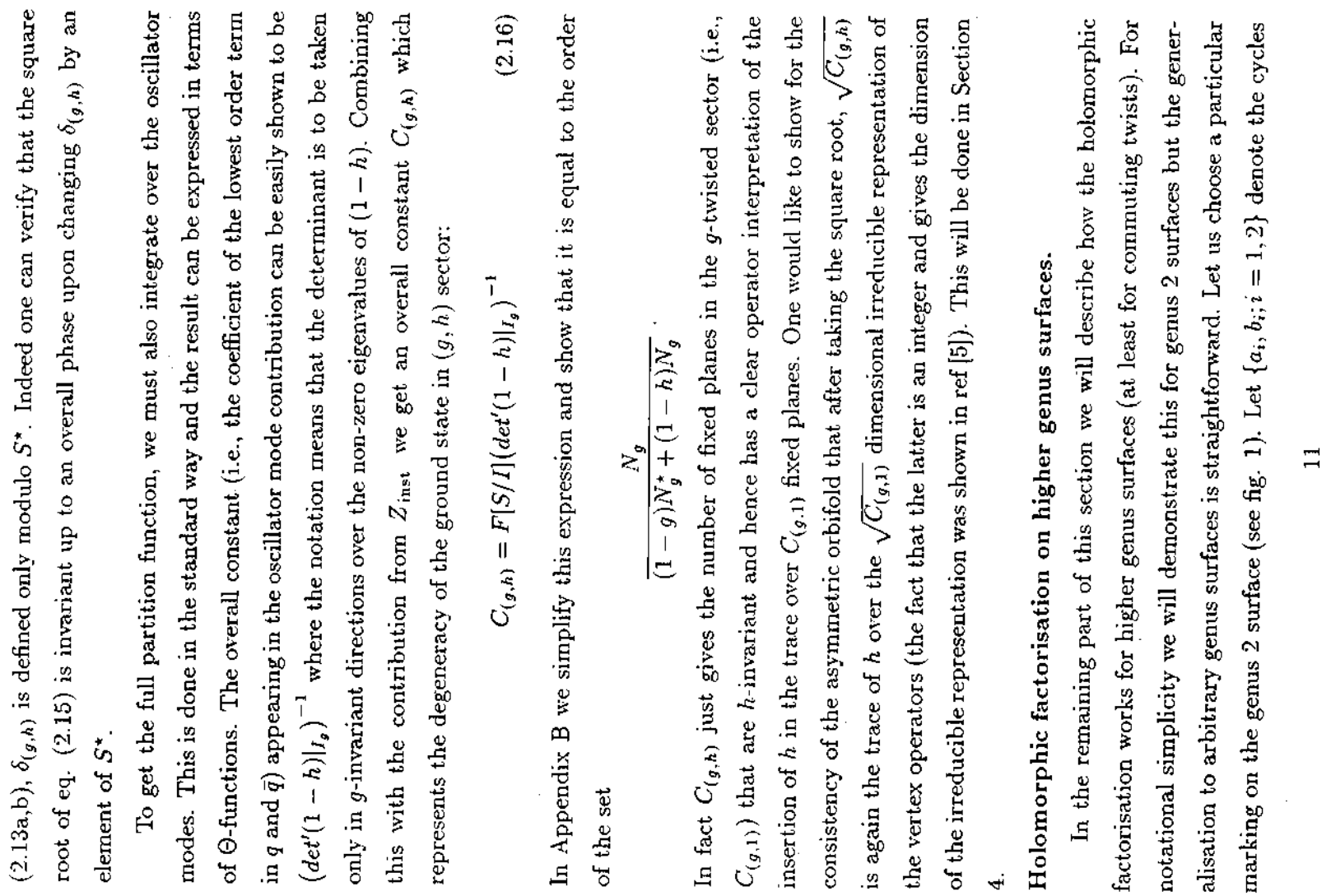



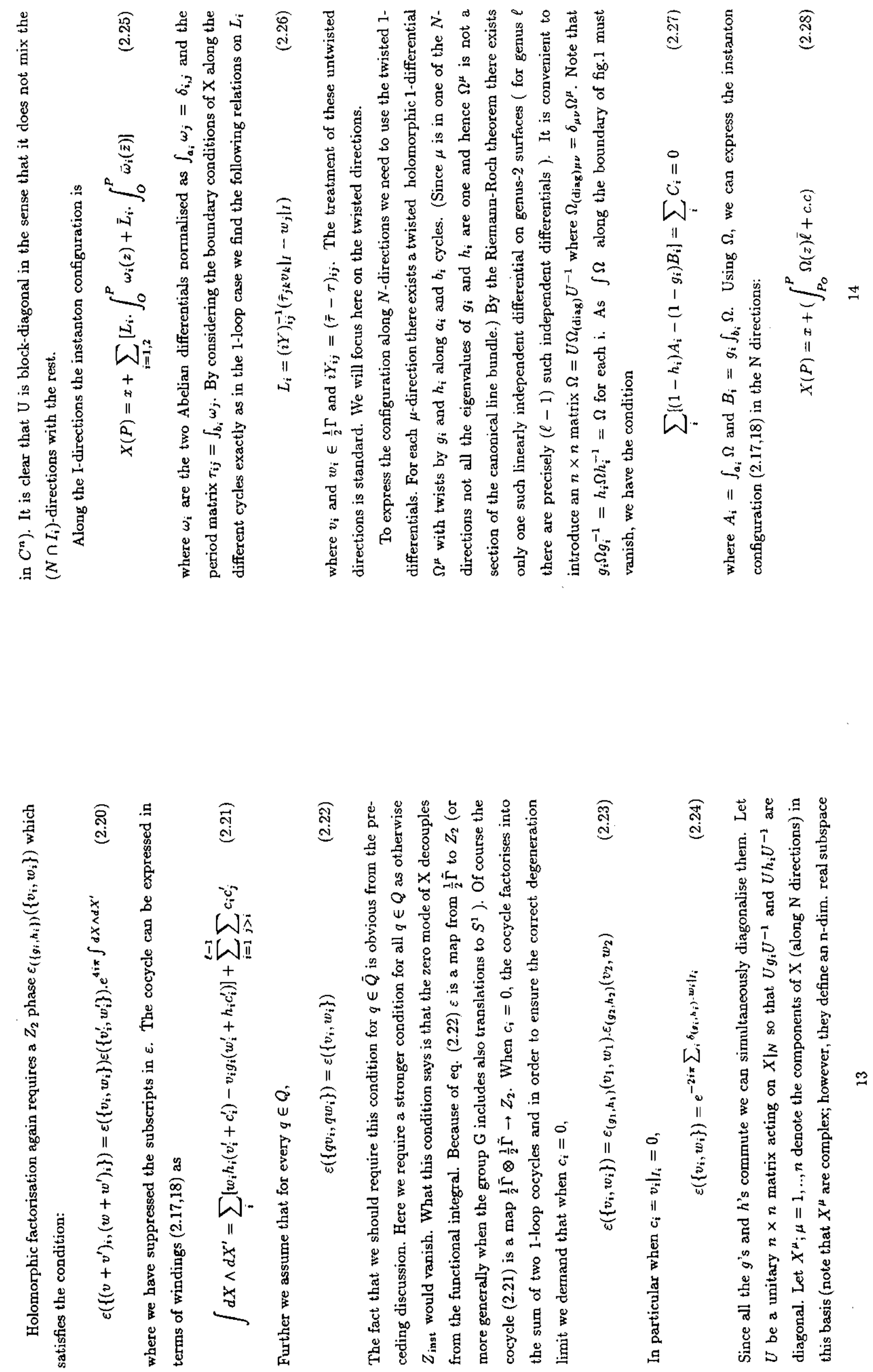

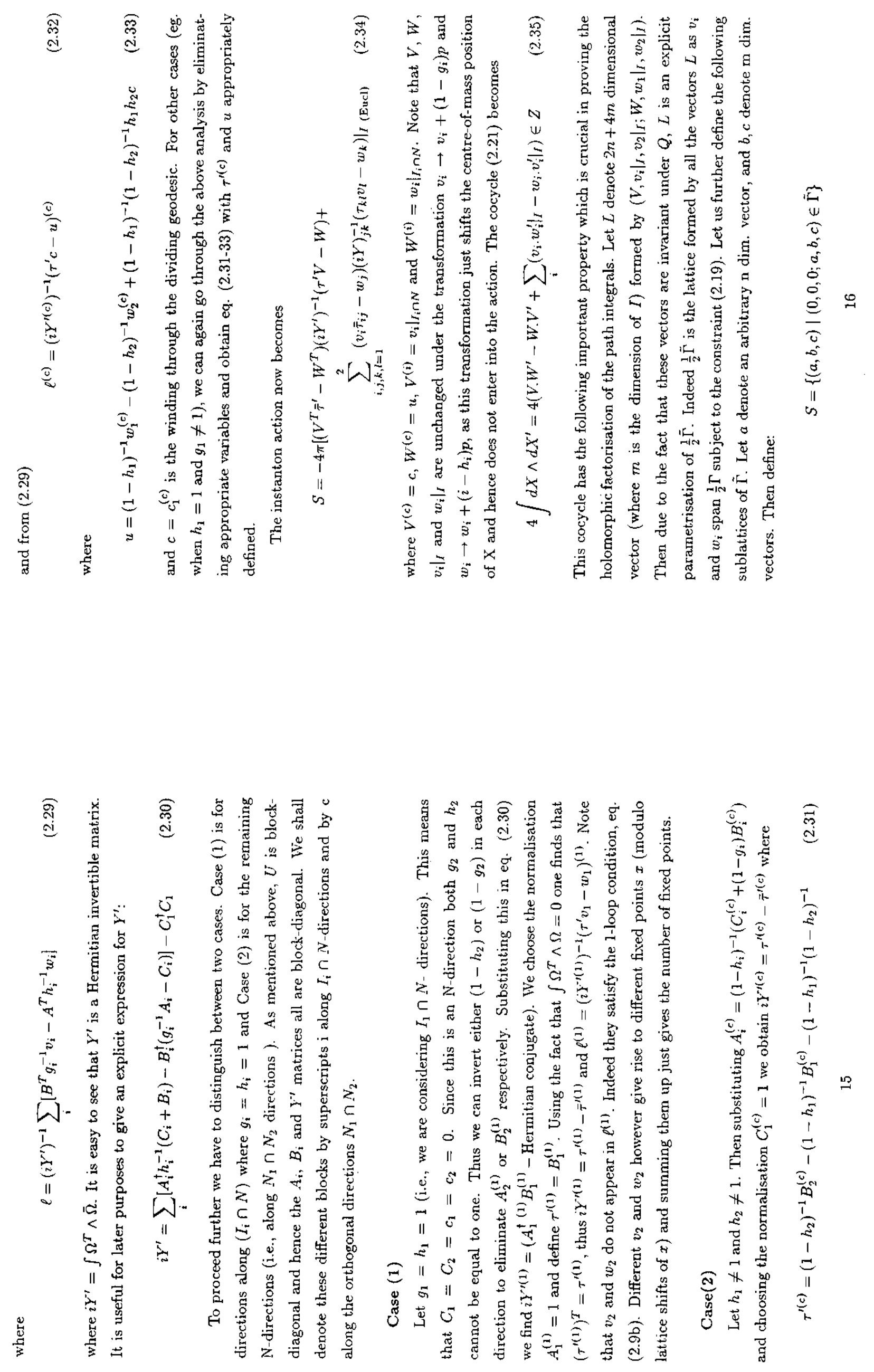

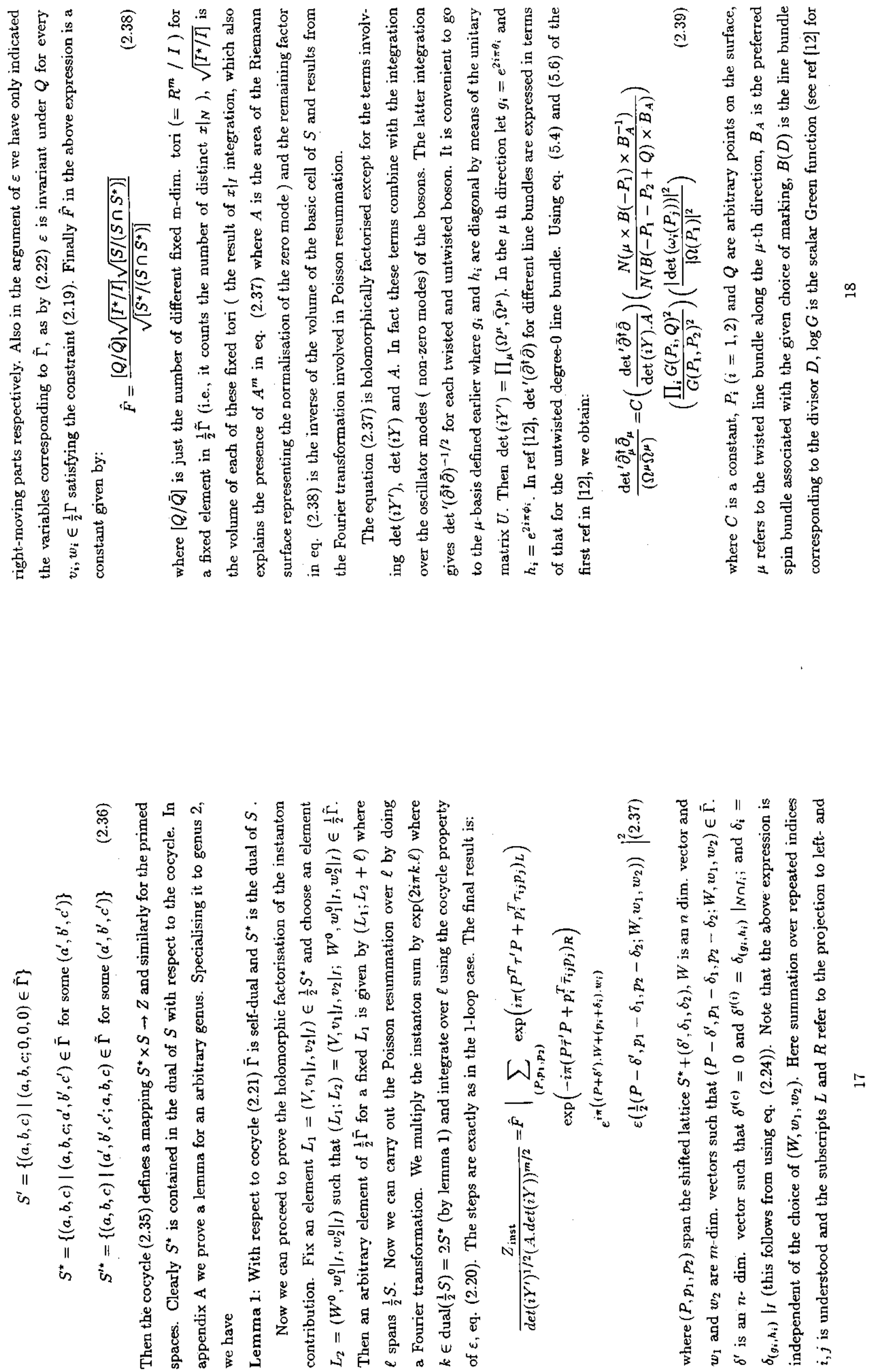

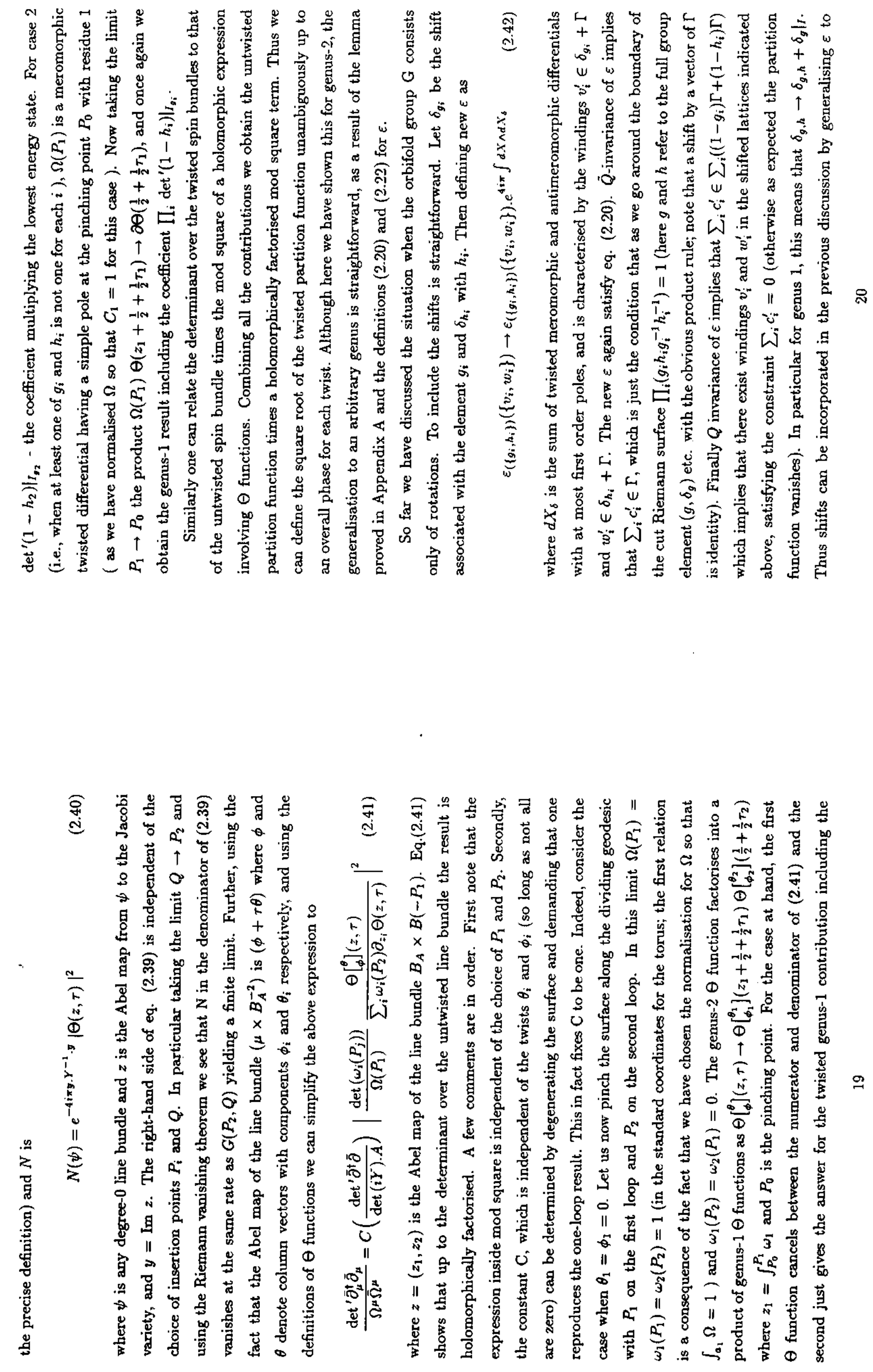

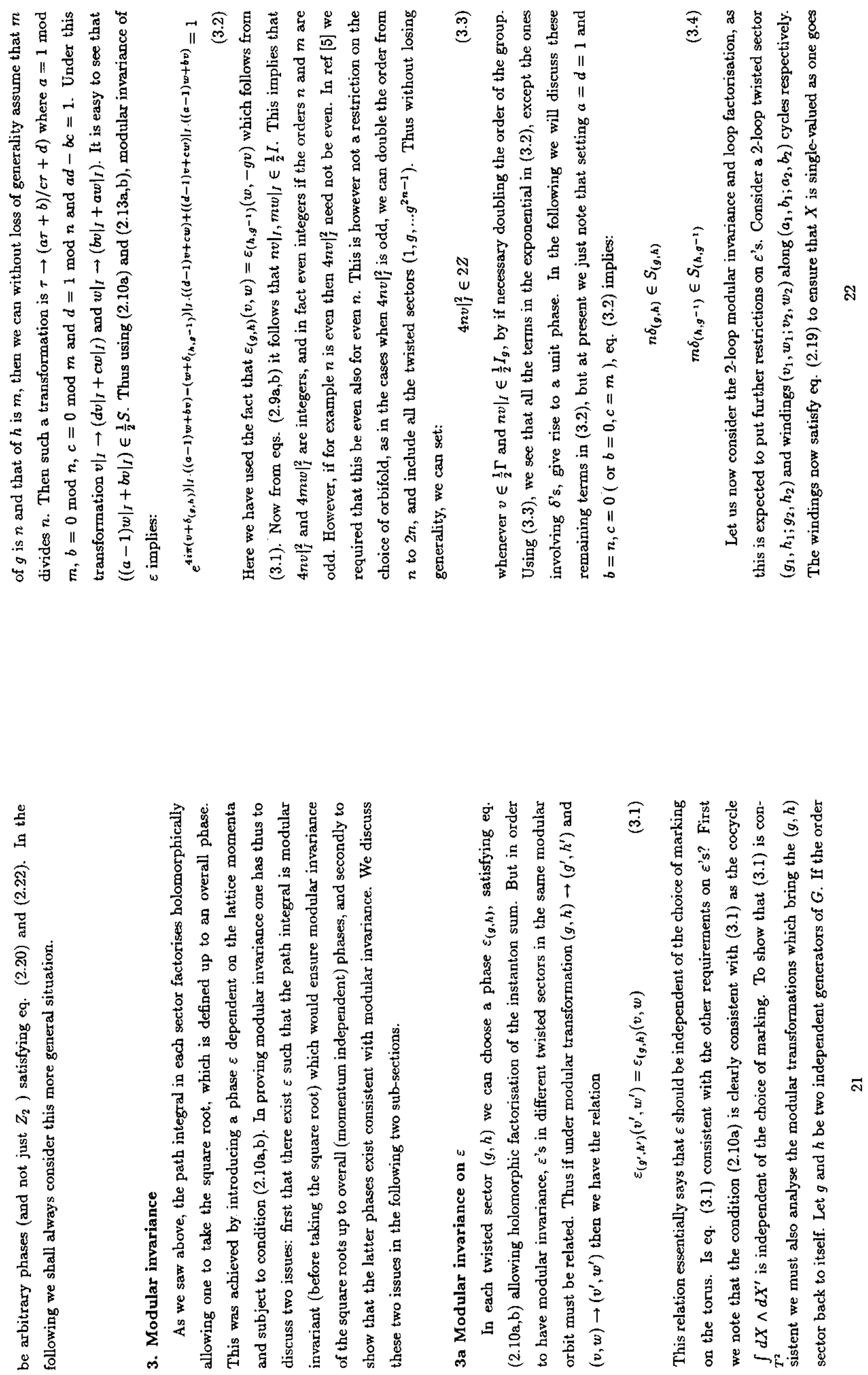


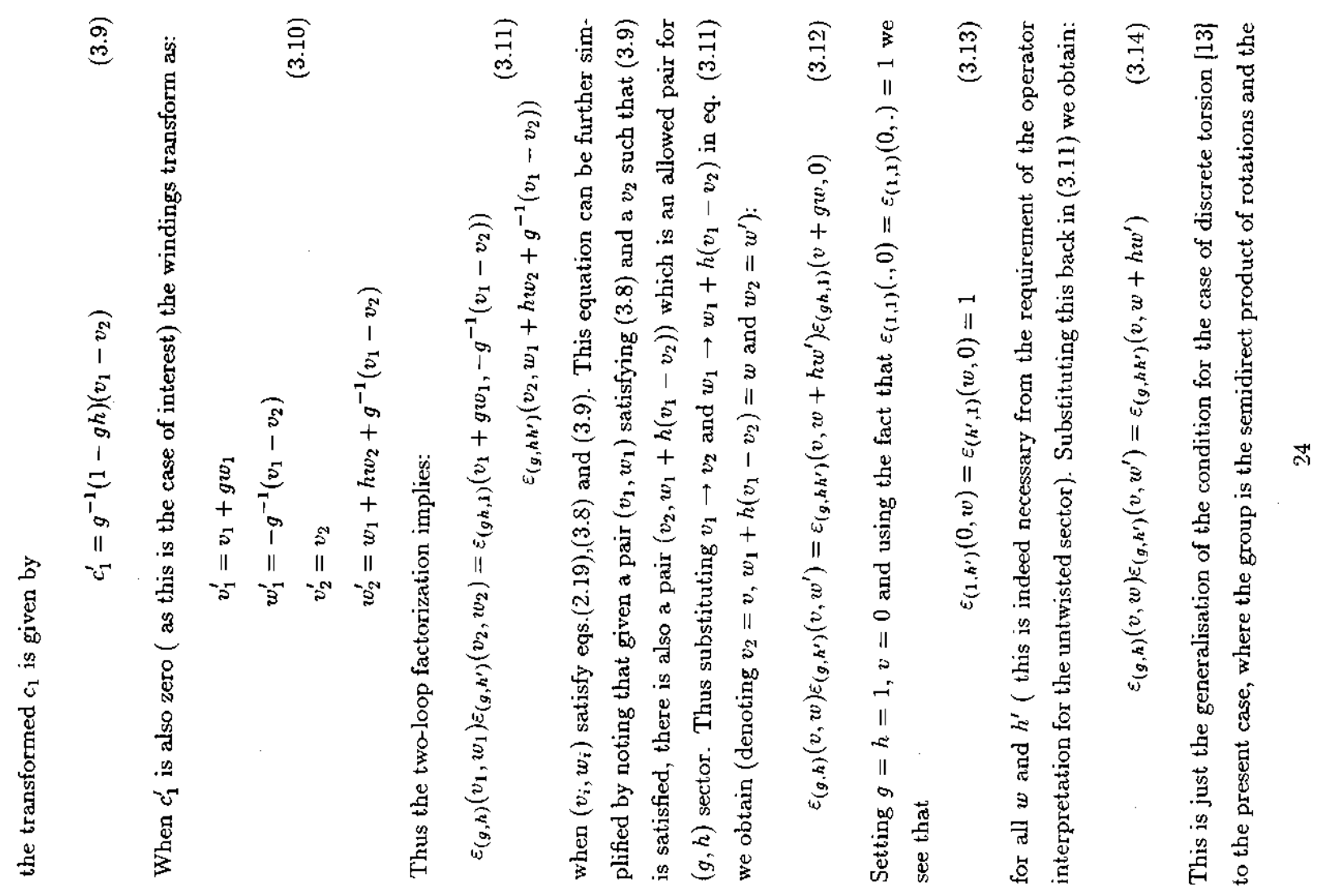

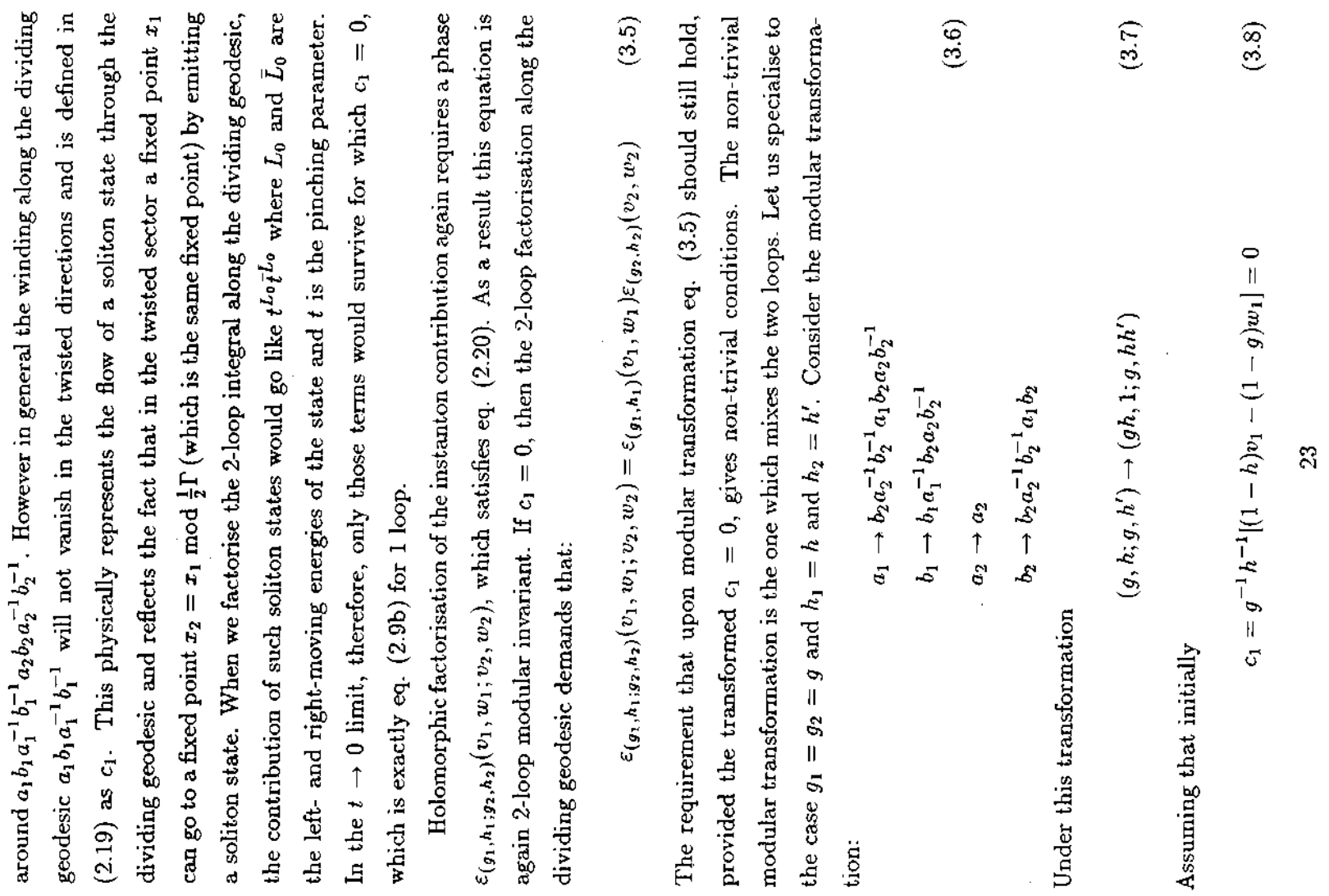



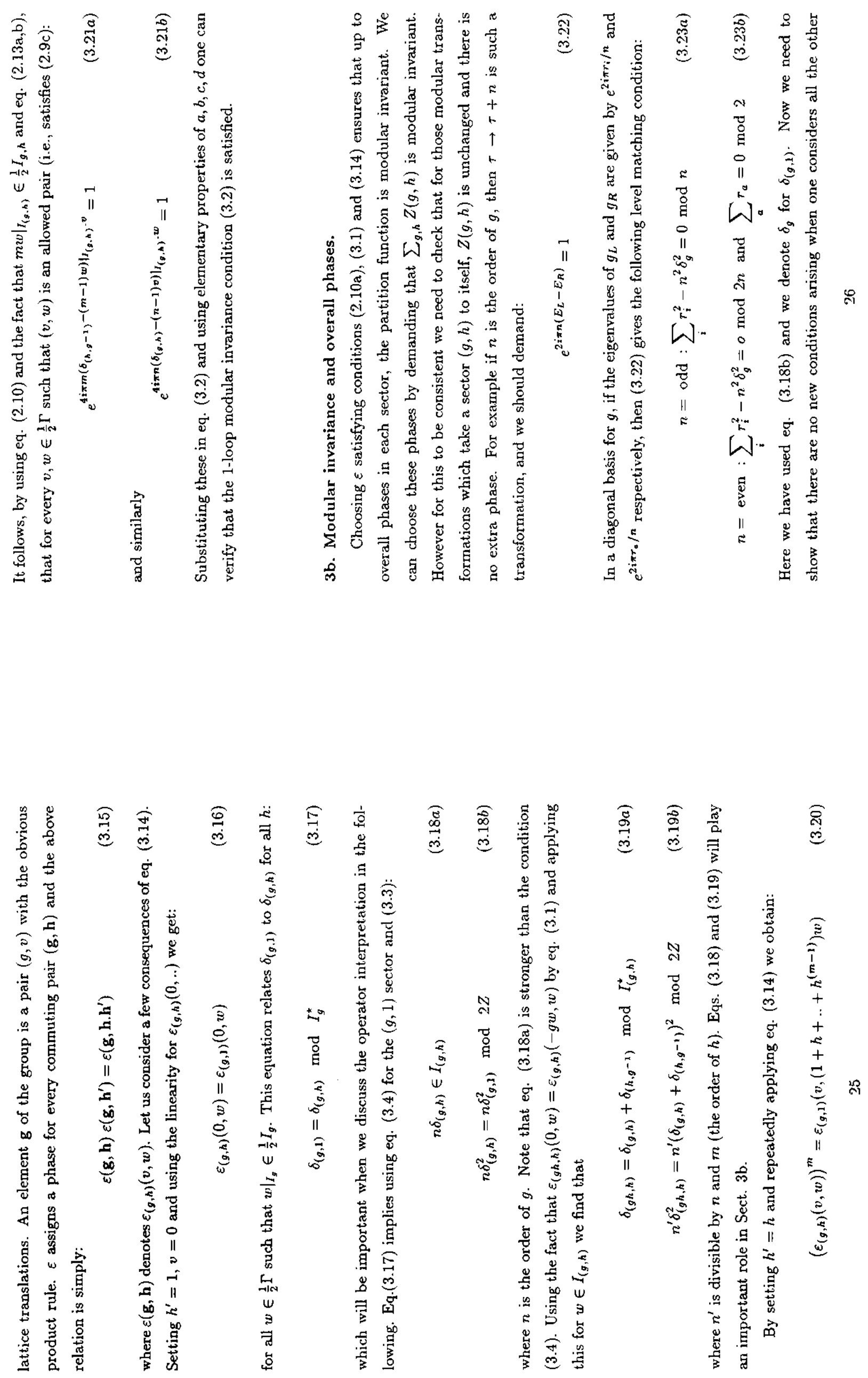

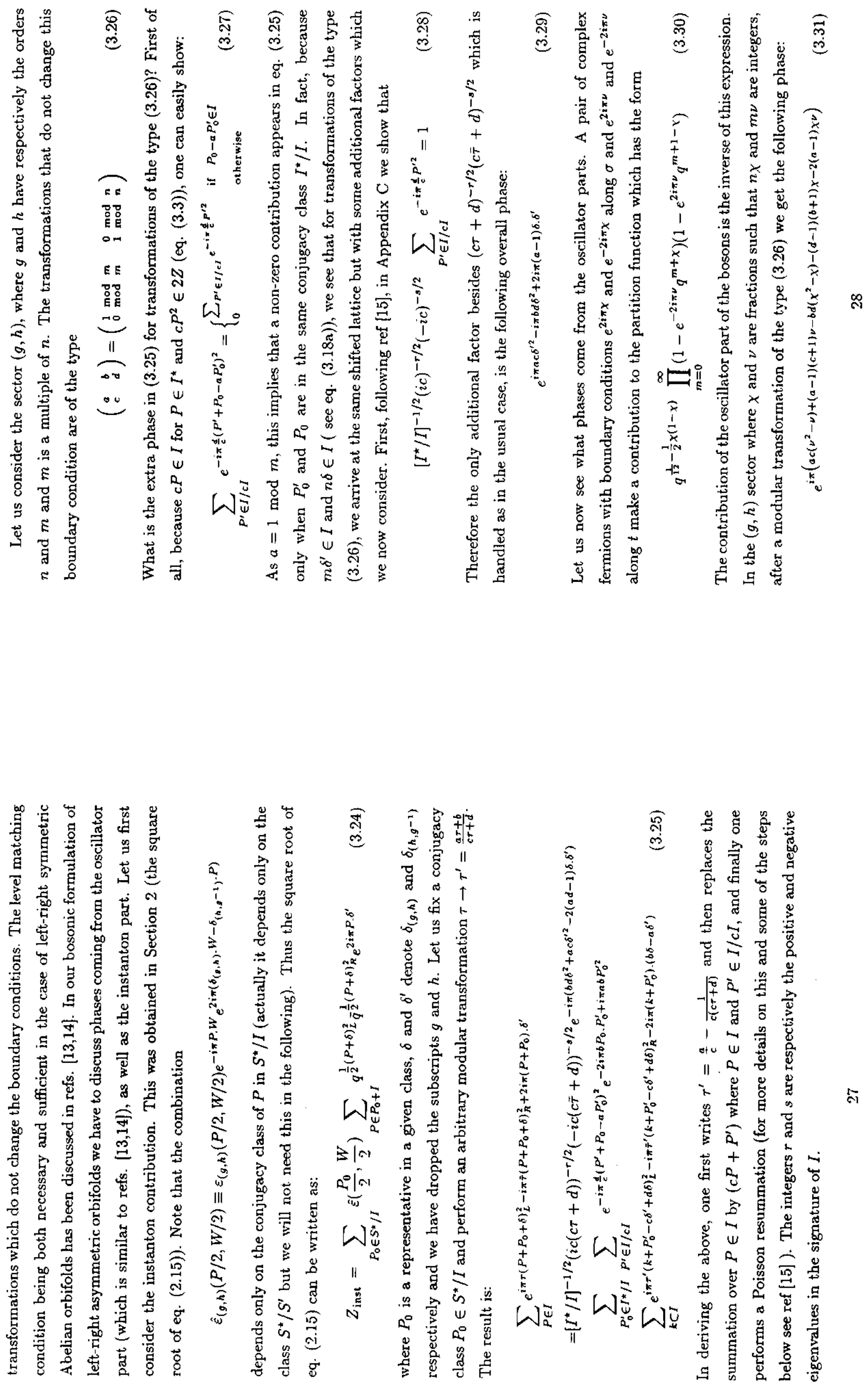


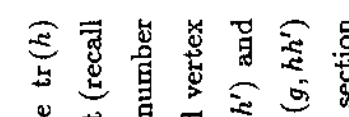

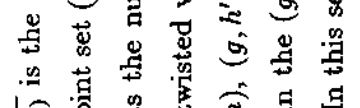

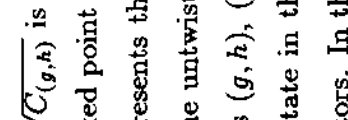

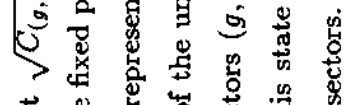

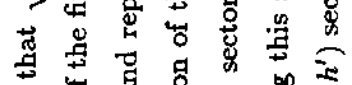

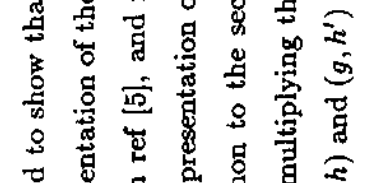

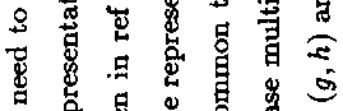

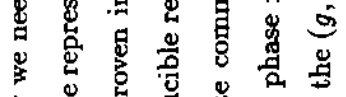

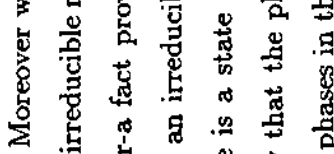

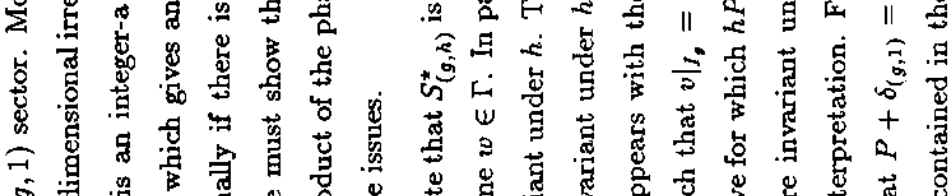

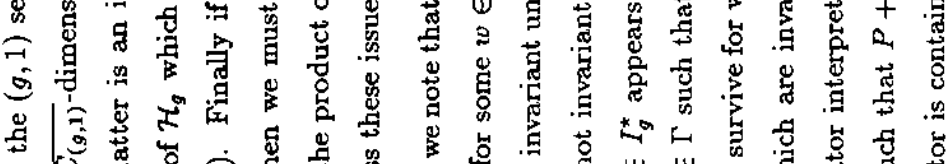
5

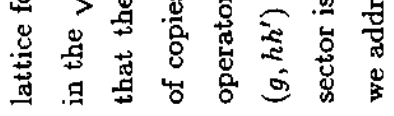

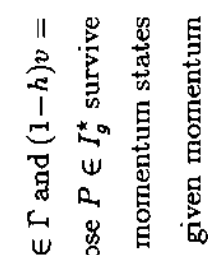

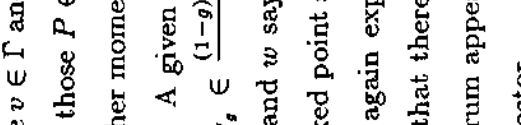

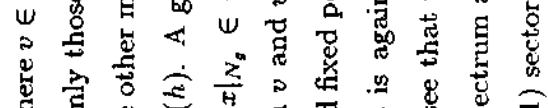

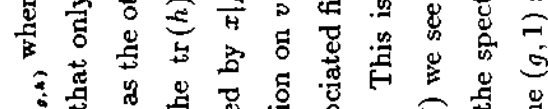

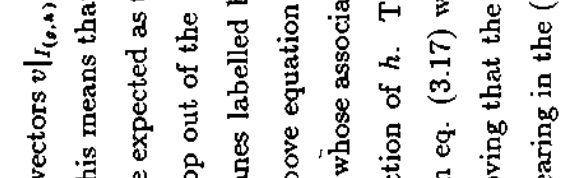

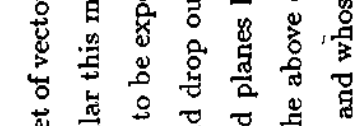

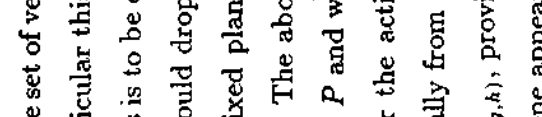

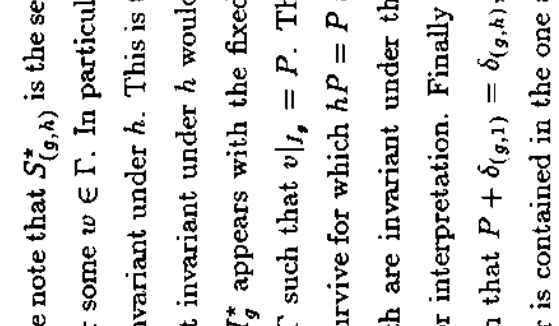

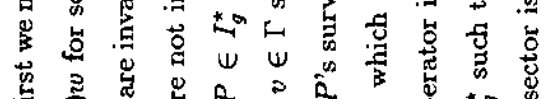
를

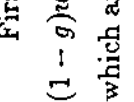

0
0

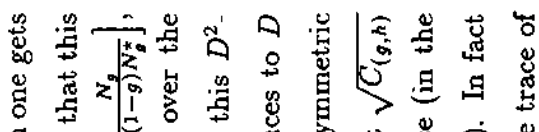

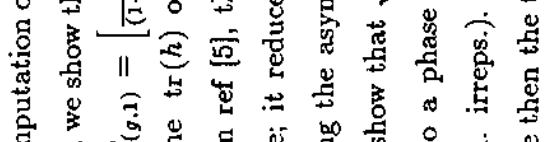

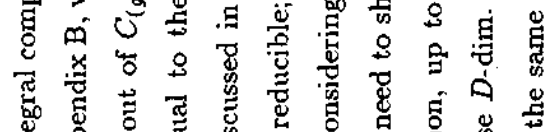

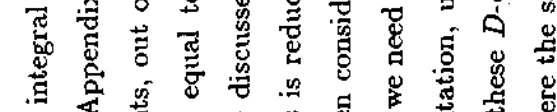

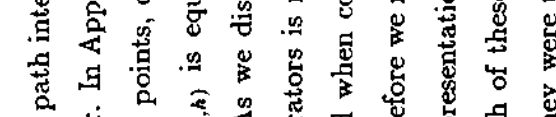

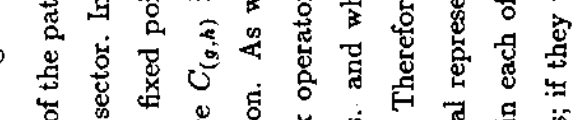



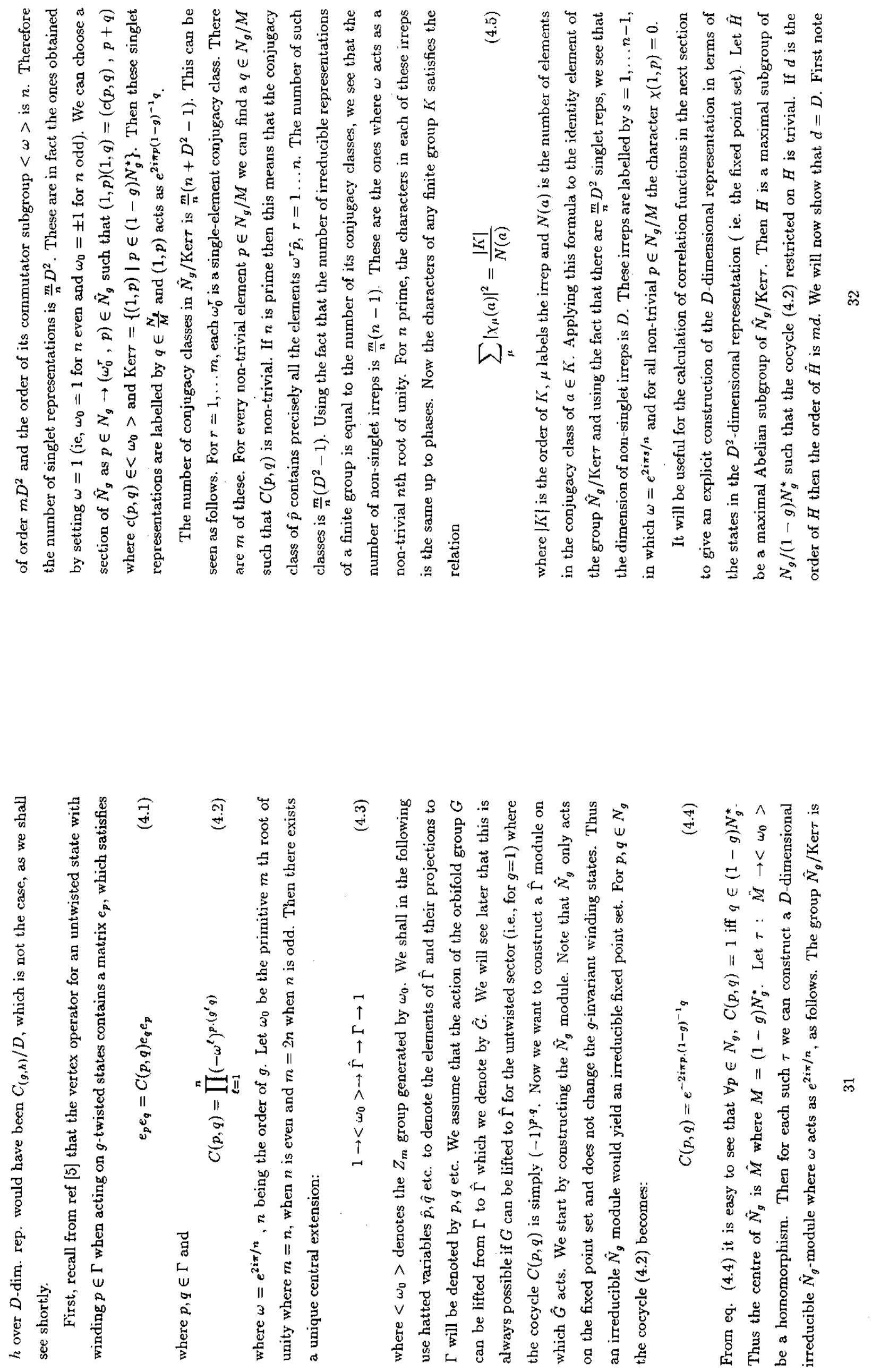

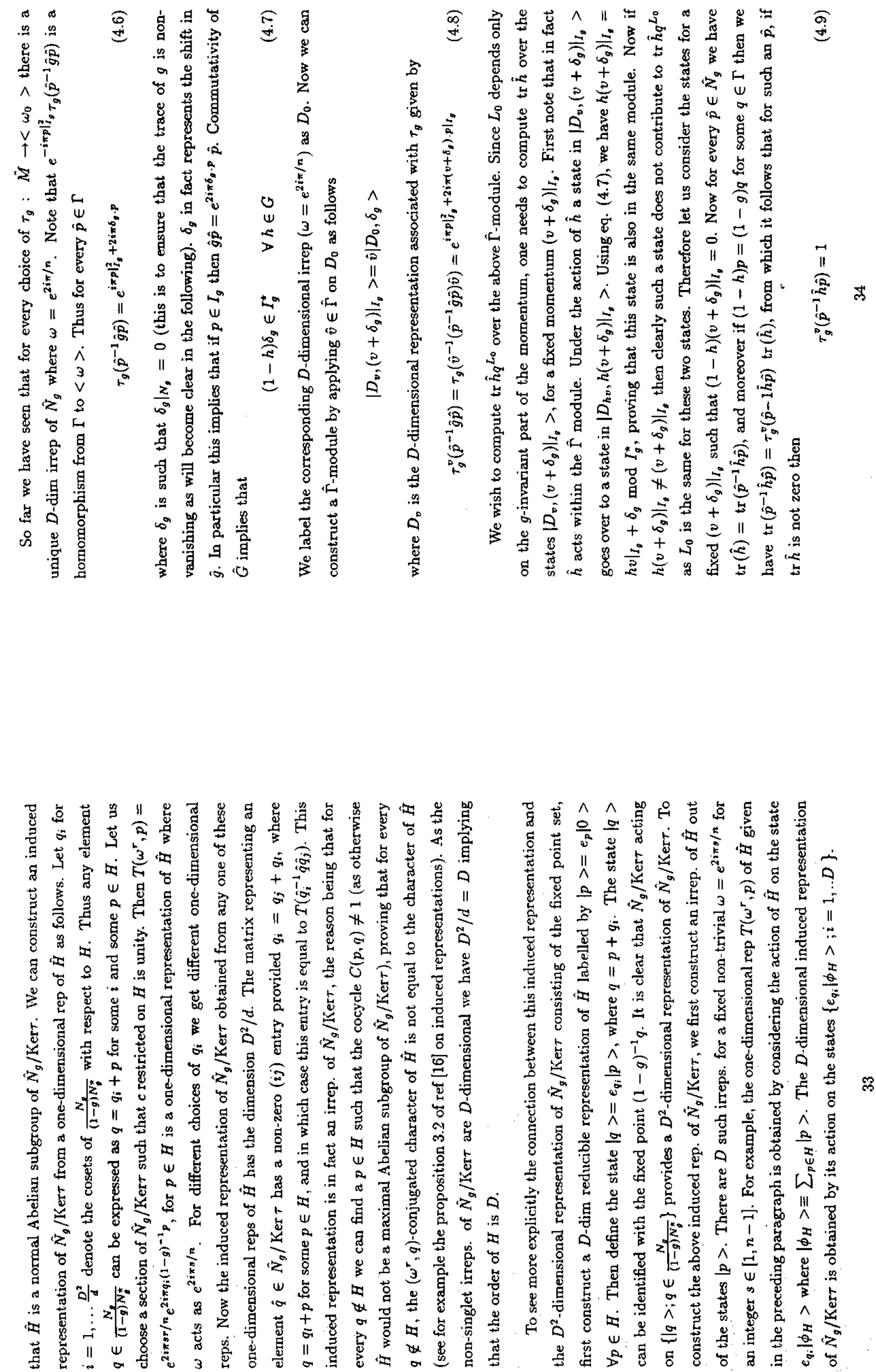

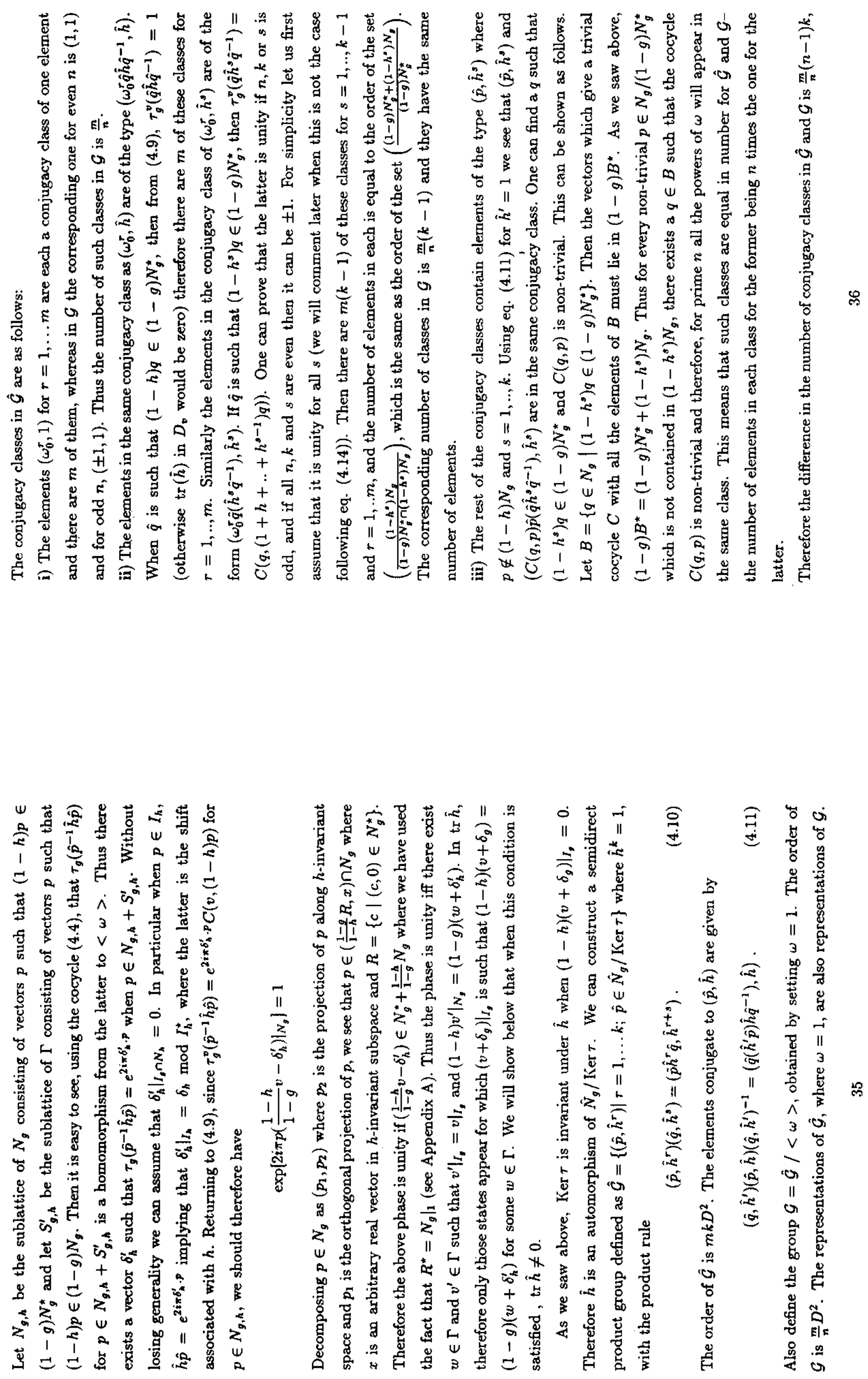


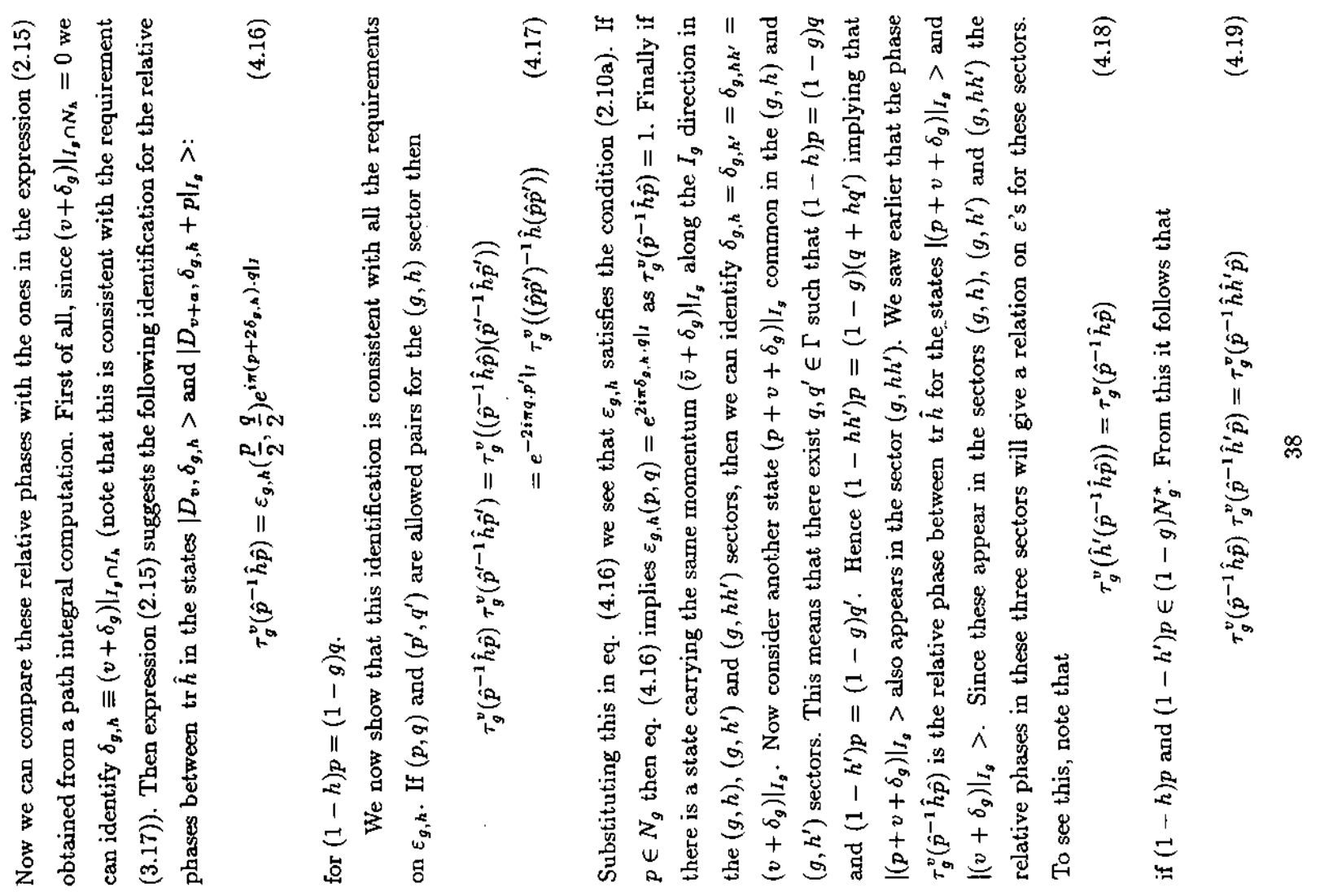

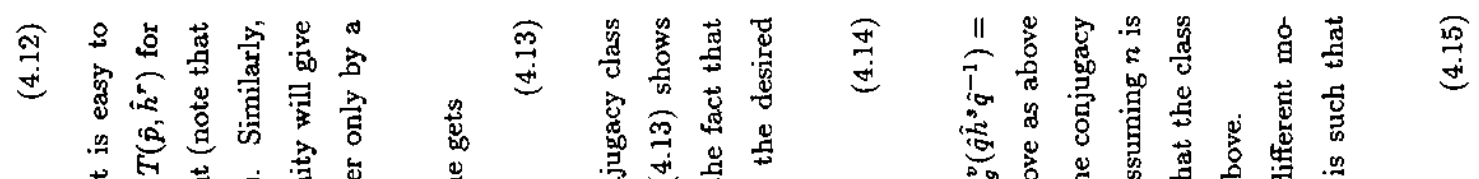

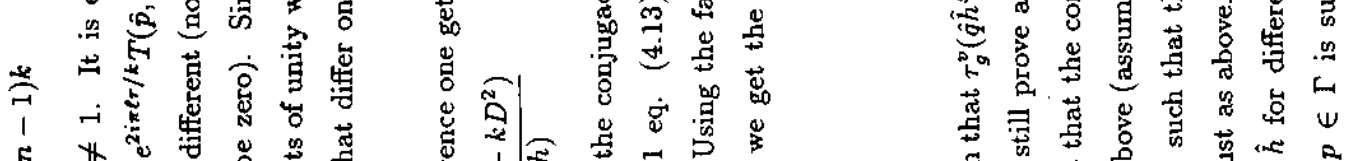

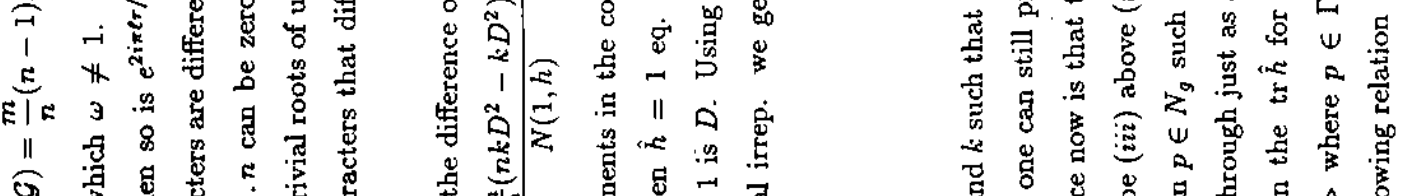



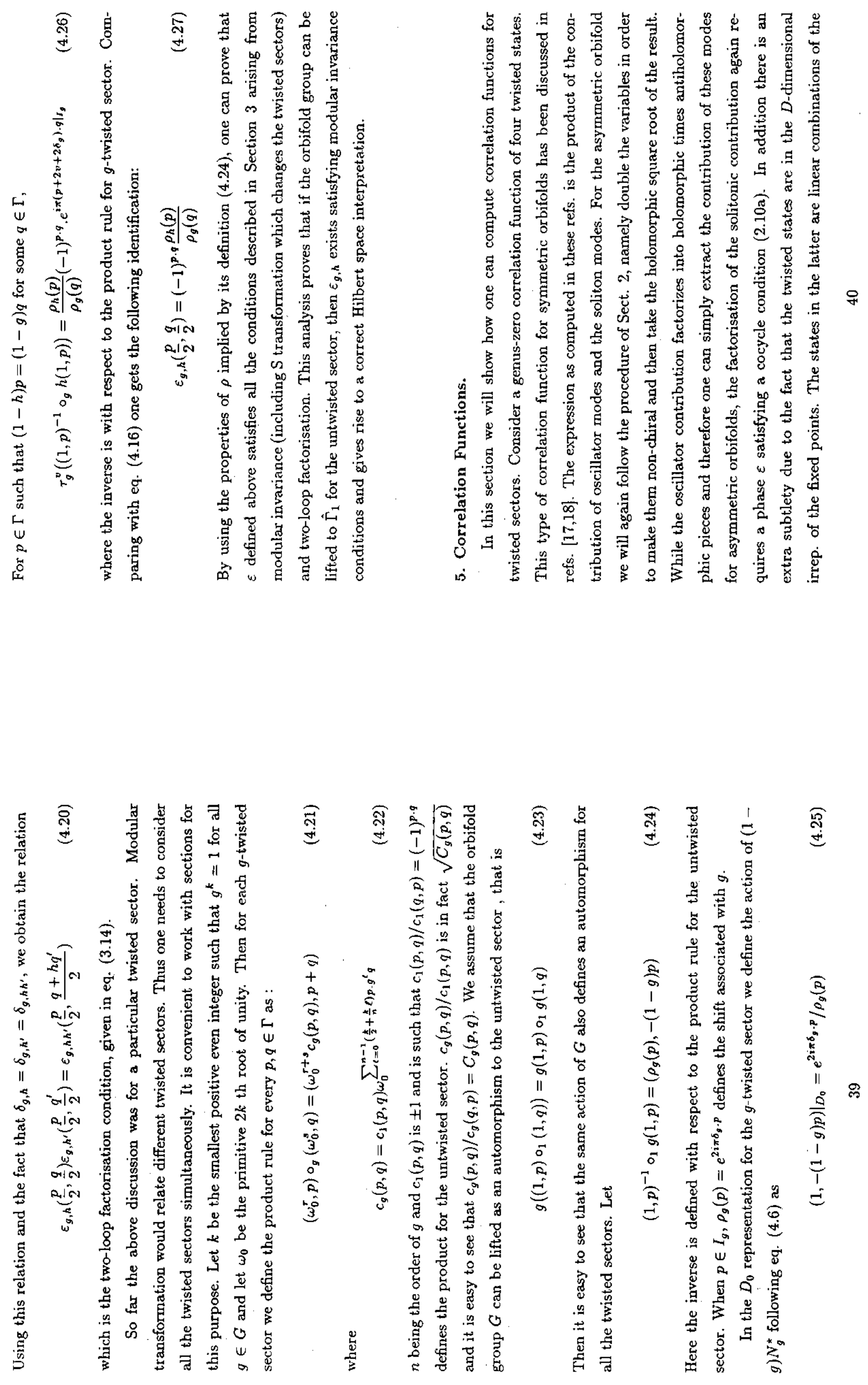


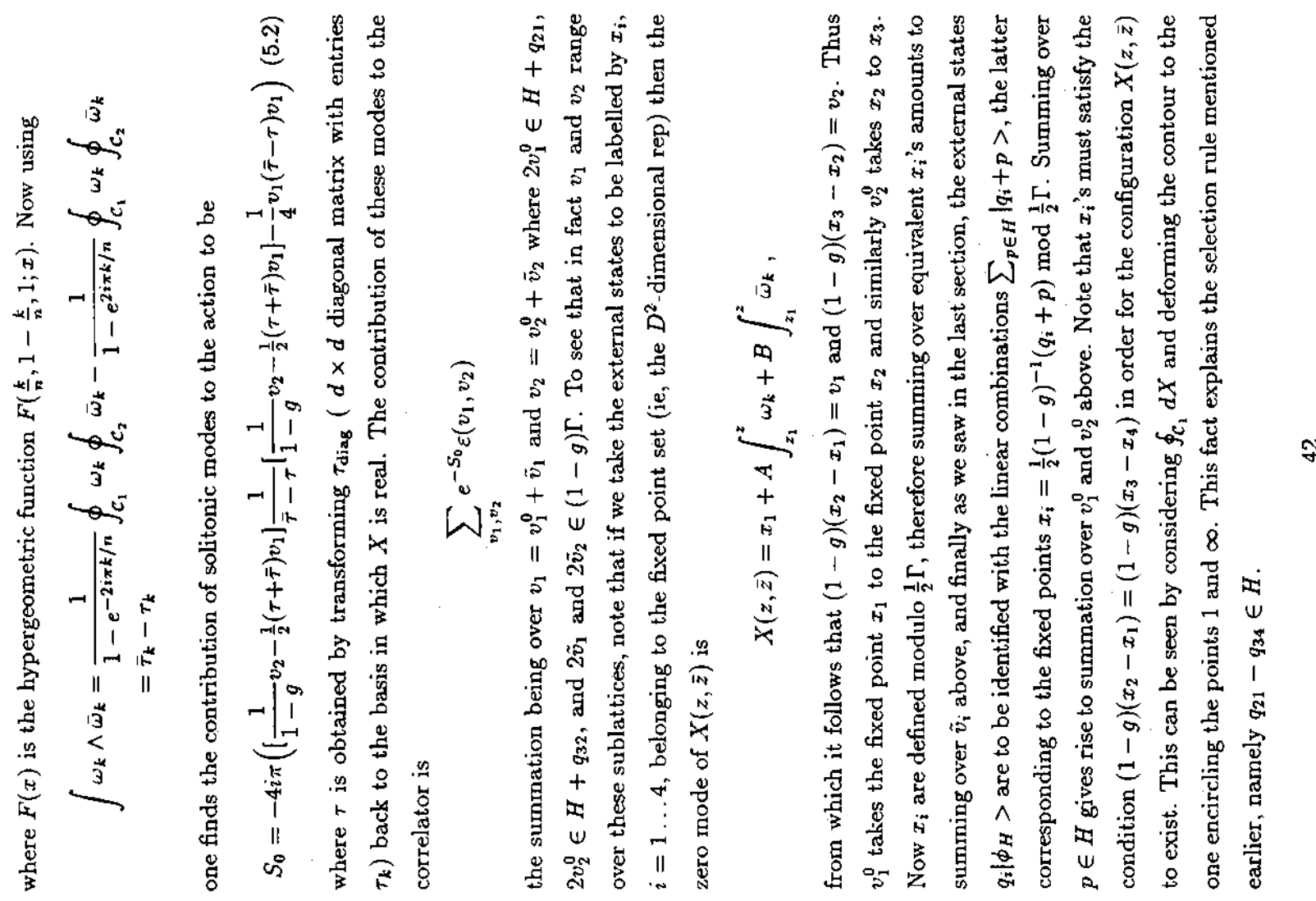

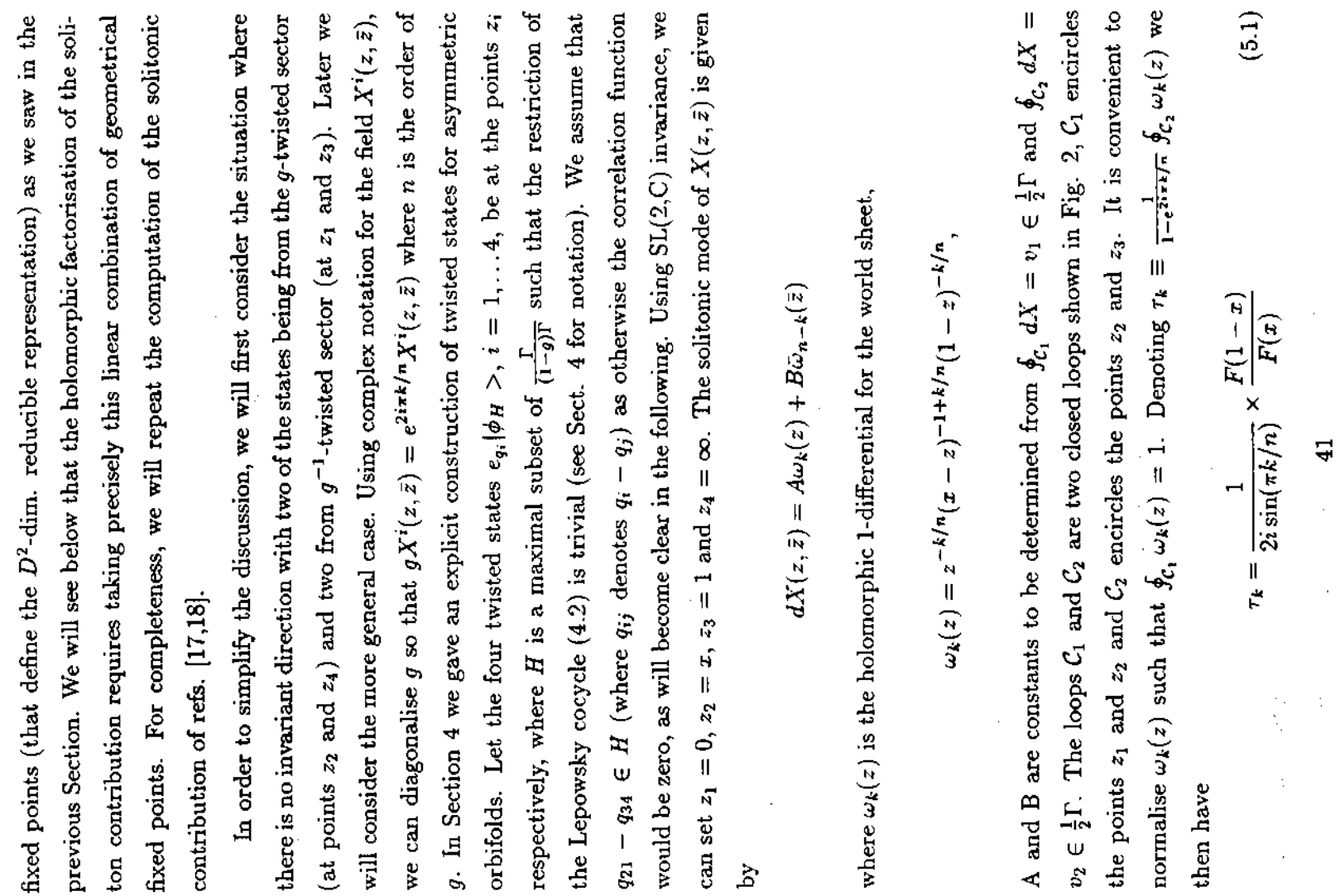



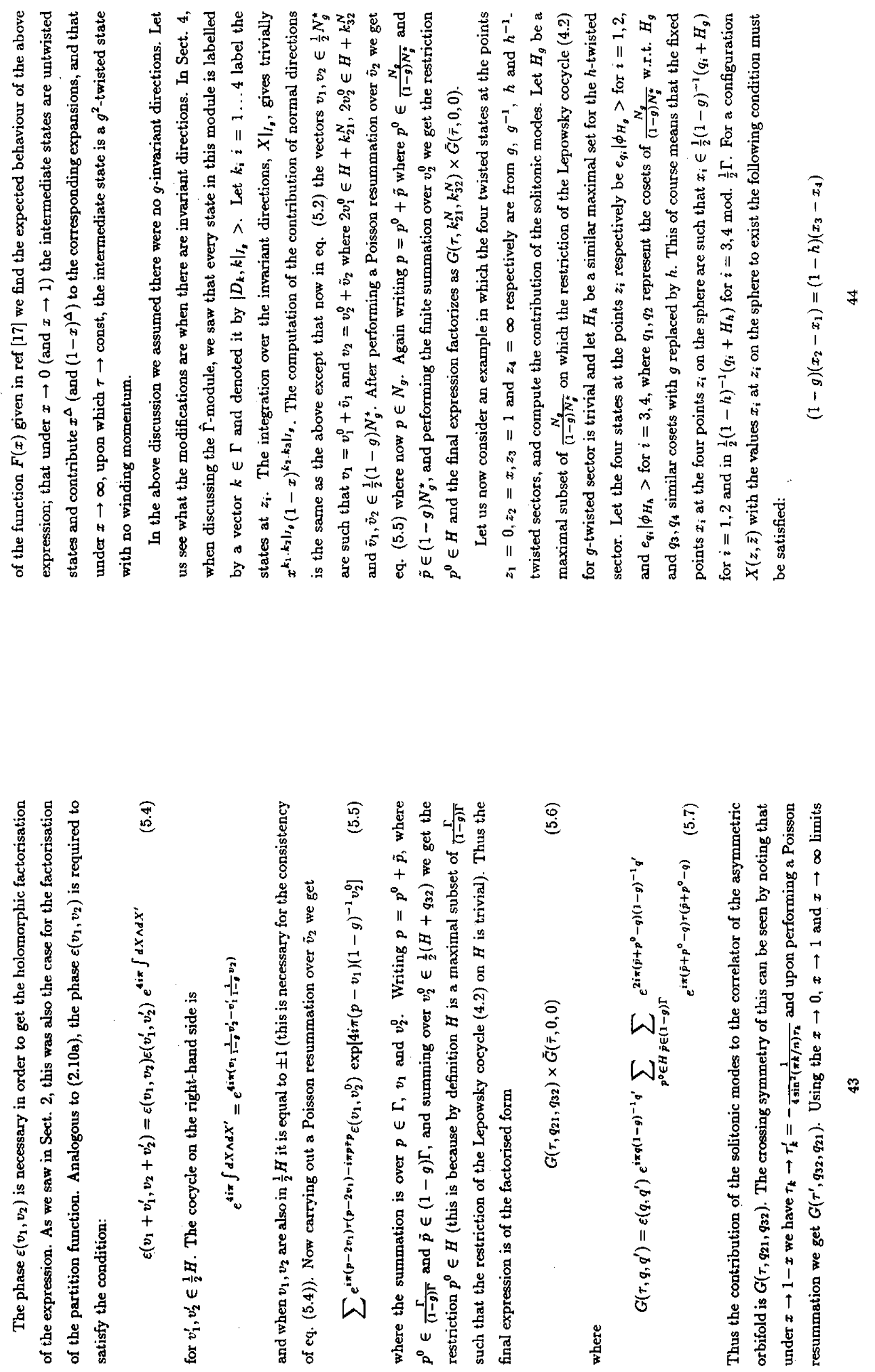

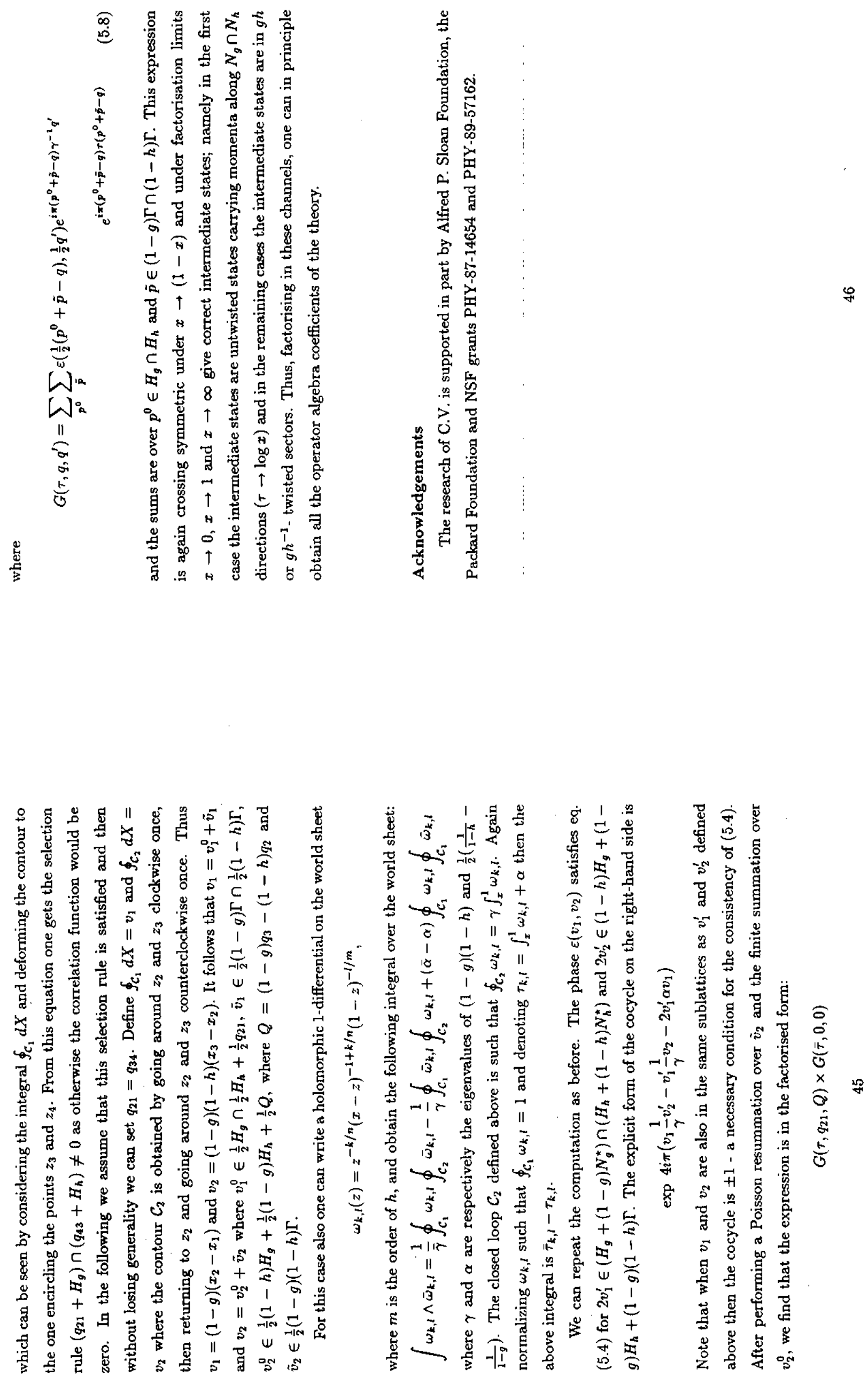

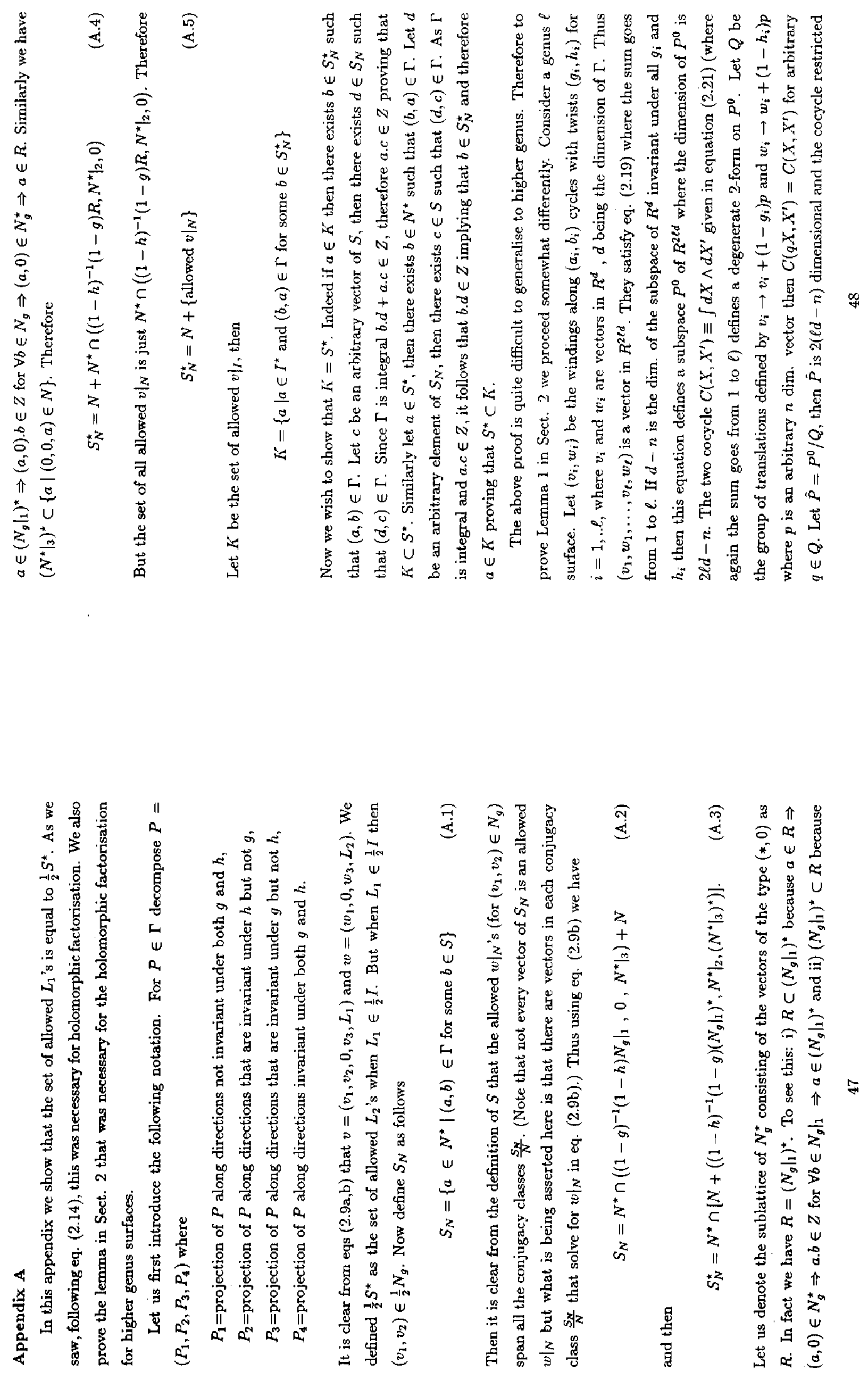

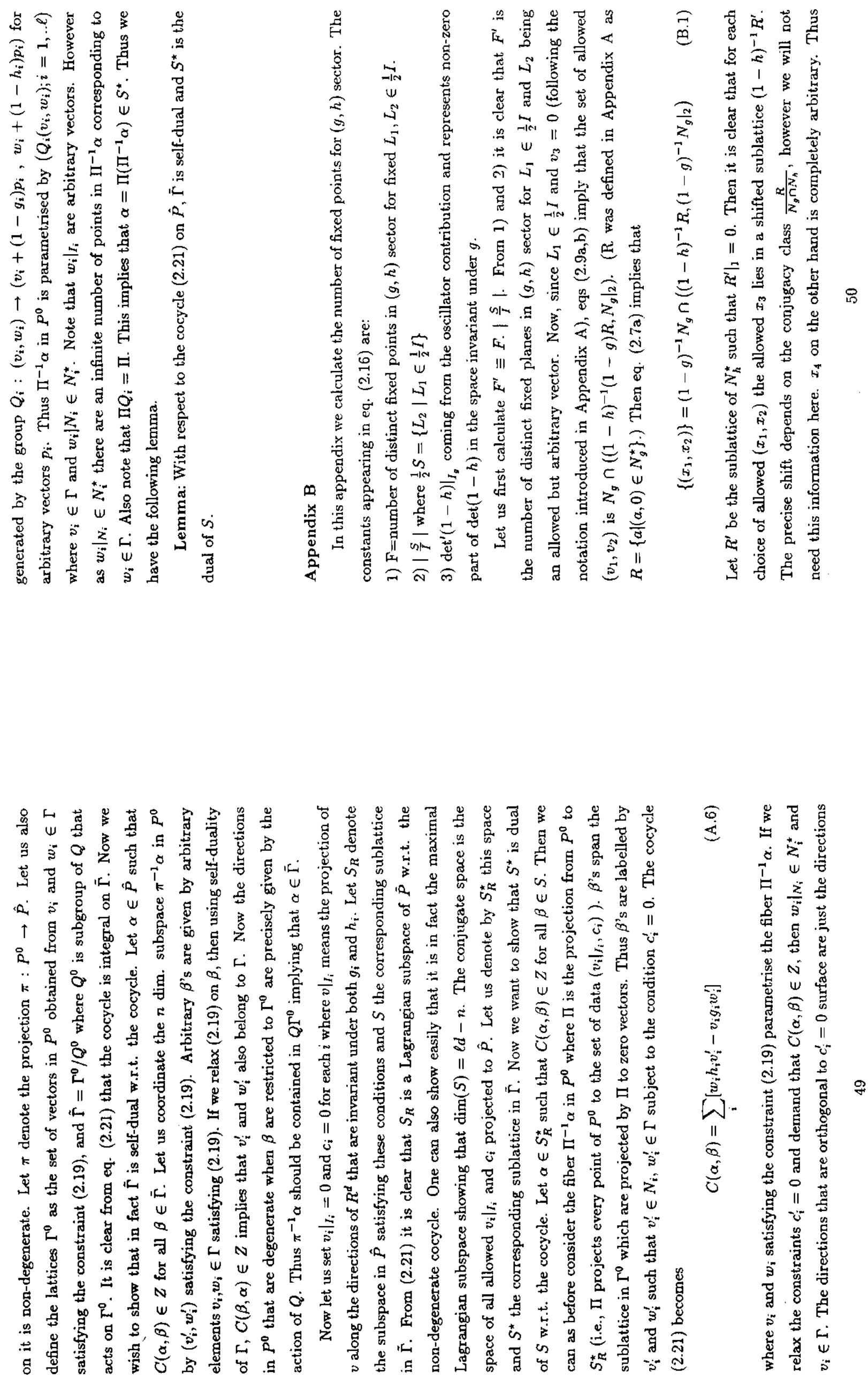


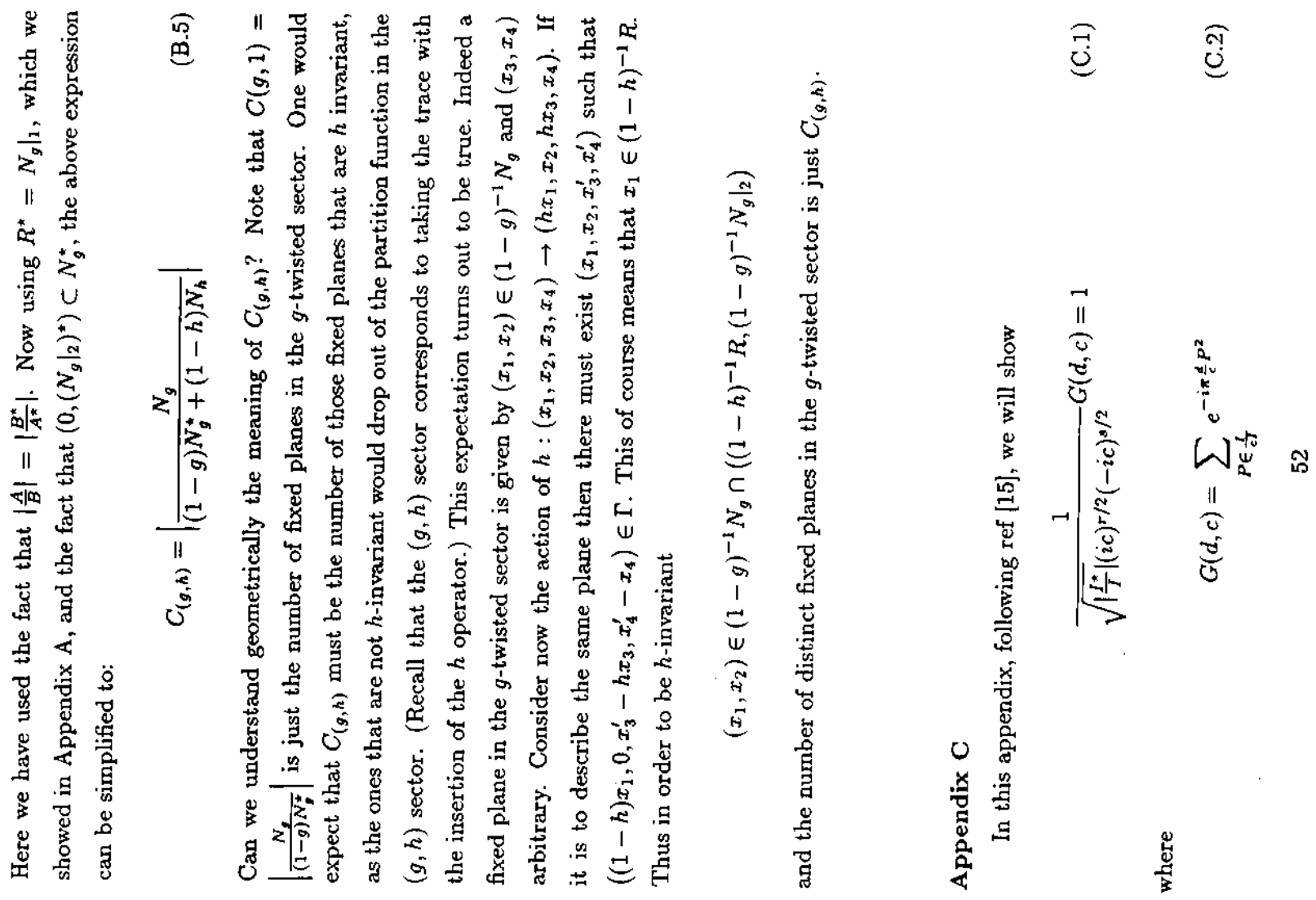

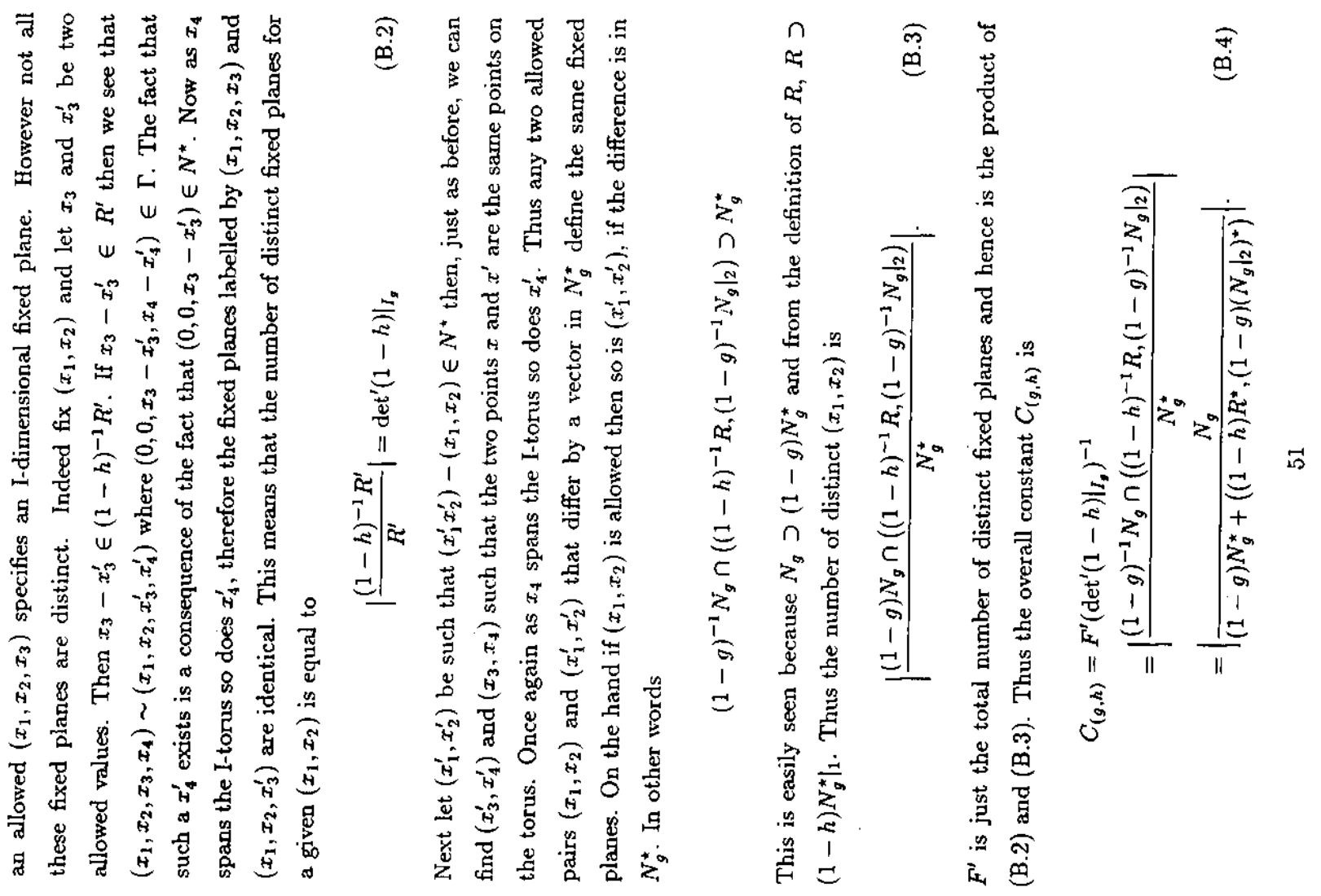



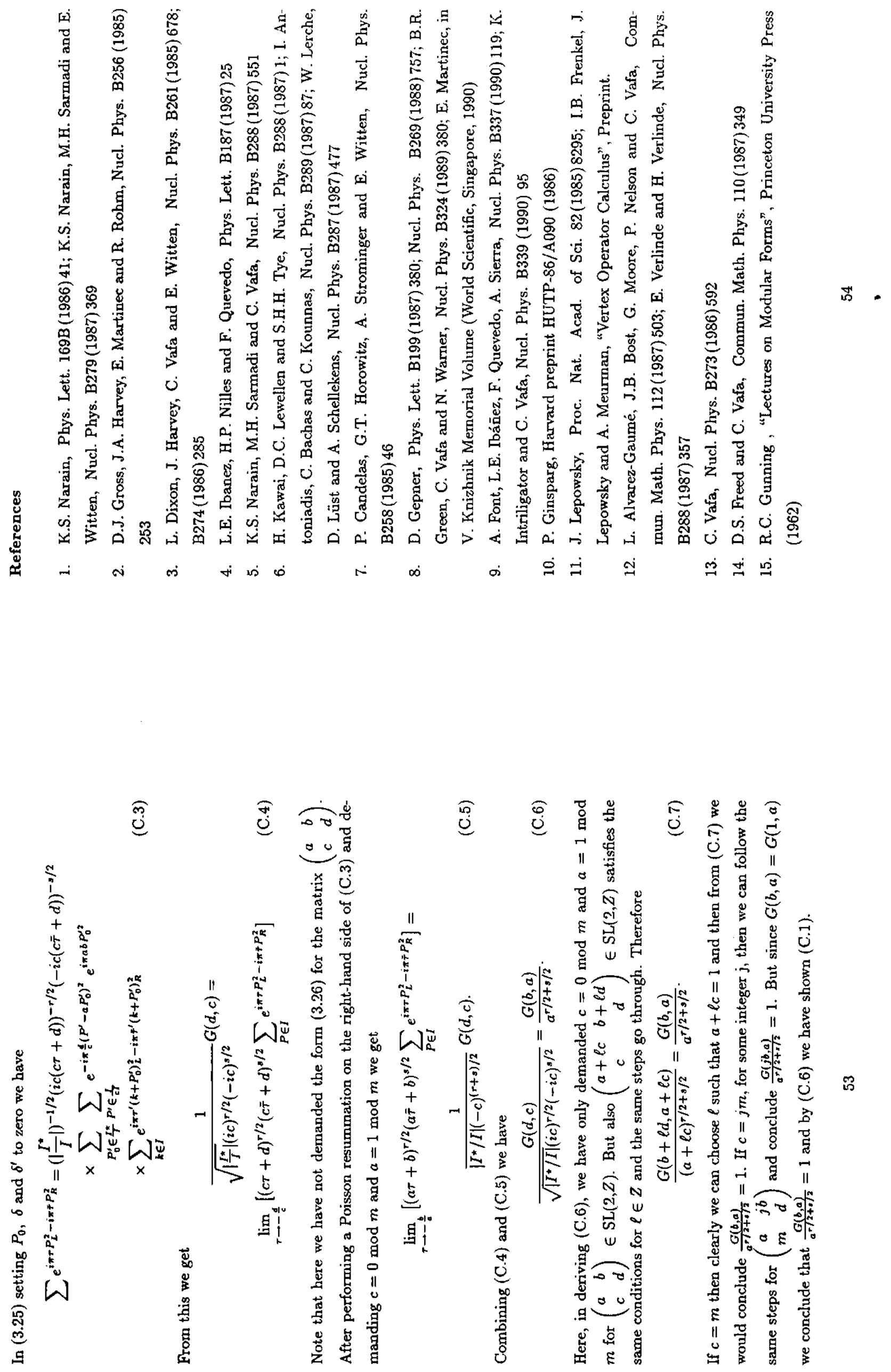

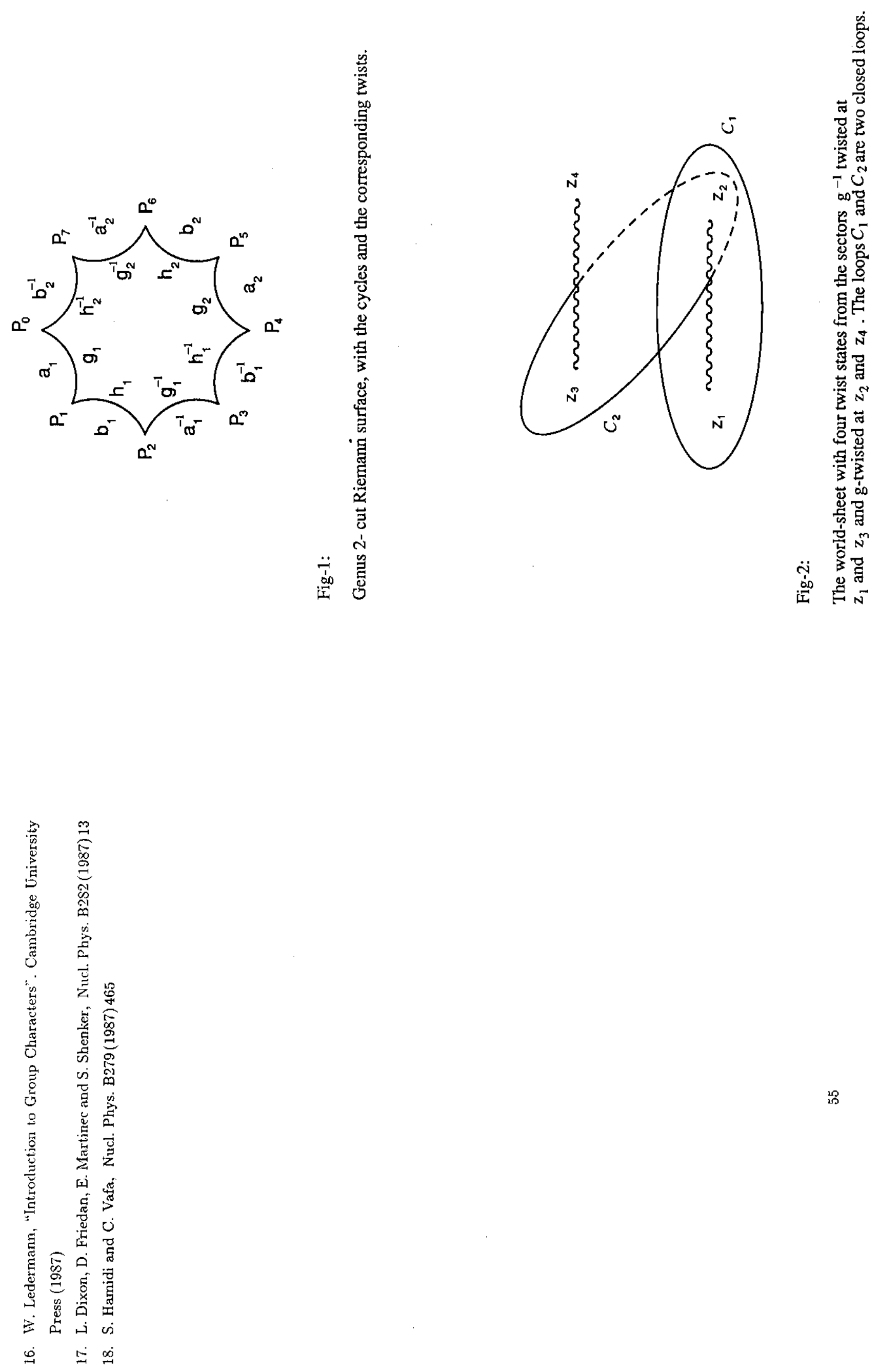